\title{
New bryozoans from the Upper Ordovician of Morocco and their place in the temperate-to-cool water Mediterranean Province
}

\author{
ANDREA JIMÉNEZ-SÁNCHEZ, ANDREJ ERNST, EMMANUELLE VENNIN \& ENRIQUE VILLAS
}

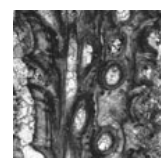

\begin{abstract}
A new study of the Upper Ordovician bryozoans belonging to the families Aisenvergiidae, Amplexoporidae, Arthrostylidae, Enalloporidae, Halloporidae, Heterotrypidae, Mesotrypidae, Ptilodictyidae, Rhinidictyidae and Trematoporidae from the eastern Anti-Atlas of Morocco is presented here. These bryozoans come from the calcarenitic levels of the Khabt-el-Hajar Formation, upper Katian, where for the first time the orders Fenestrata and Cryptostomata are described in this formation. This fauna inhabited an upper offshore environment and represent high-energy deposits, typical of a shore face environment, as well as storm-induced deposits. A total of 15 species included in 13 genera, 10 of them only identified in the calcarenitic levels of the Khabt-el-Hajar Formation, and two incertae sedis taxa are described. A new species, Trematopora vesiculata, is defined. An update of the Upper Ordovician bryozoan presence/absence database, including the 22 genera described in total in the Khabt-el-Hajar Formation, has been carried out. The augmented database has been analysed with two multivariate statistical techniques: detrended correspondence analysis (DCA) and principal coordinate analysis (PCO), in order to assess the palaeogeographic affinity of this fauna, and the results show that Moroccan bryozoans, in spite of belonging to the fauna developed in the highest latitudes during the upper Katian, have a clear Mediterranean affinity. $\bullet$ Key words: Bryozoa, Ordovician, late Katian, Anti-Atlas, Morocco, high and middle-high latitude, Mediterranean region.
\end{abstract}

JimÉNEZ-SÁNCHEZ, A., ERnST, A., Vennin, E. \& Villas, E. 2016. New bryozoans from the Upper Ordovician of Morocco and their place in the temperate-to-cool water Mediterranean Province. Bulletin of Geosciences 91(1), 23-50 (9 figures, 17 tables). Czech Geological Survey, Prague. ISSN 1214-1119. Manuscript received June 11, 2015; accepted in revised form October 7, 2015; published online December 4, 2015; issued March 17, 2016.

Andrea Jiménez-Sánchez (corresponding author), Center of Biology, Geosciences and Environmental Education, University of West Bohemia, Klatovská 51, 30619 Plzeň, Czech Republic. Now in: University of Zaragoza (Spain); andreaj@unizar.es•Andrej Ernst, Institut für Geologie, Universität Hamburg, Bundesstr. 55, D-20146 Hamburg, Germany; Andrej.Ernst@uni-hamburg.de•Emmanuelle Vennin, Biogéosciences, Université de Bourgogne, 6 bd. Gabriel, 21000 Dijon, France; emmanuelle.vennin@u-bourgogne.fr • Enrique Villas, Departamento de Ciencias de la Tierra, Facultad de Ciencias, Universidad de Zaragoza, C/ Pedro Cerbuna 10, 50009 Zaragoza, Spain; villas@unizar.es

During the whole Ordovician the North African Gondwana platforms were mostly dominated by siliciclastic sedimentation, even during the late Katian when carbonate deposits became widely spread on the rest of the Mediterranean platforms. While those carbonate platforms of Iberia, Armorica, Pyrenees, Montagne Noire, Sardinia, Carnic Alps and Tripolitania (Libya) were extensively colonized by a diverse group of invertebrates (Vennin et al. 1998), the benthic associations on siliciclastic substrates of the Anti-Atlas region never reached diversity peaks significantly higher than in previous Ordovician times. For instance, the rich Nicolella brachiopod fauna (Havlíček 1971, Pickerill \& Brenchley 1979), so typical of late Katian times in the south-western European platforms, never colonised the North African region. Nevertheless, bryozoan associations represent locally one exception to the low diver- sity of the late Katian invertebrate assemblages in North Africa. Carbonate buildups dominated by echinoderm and bryozoan associations have been reported in Libya (Buttler \& Massa 1996, Buttler et al. 2007) and bryozoan thickets flourished locally on carbonate substrates present in distal parts of some Moroccan platforms during major flooding episodes (Álvaro et al. 2007). However, it is one area in the whole of North Africa, close to Erfoud in the eastern Anti-Atlas, which displays an extraordinary bryozoan diversity. The on-going studies on bryozoan associations of the late Katian Khabt-el-Hajar Formation have shown a diversity that parallels those of the Iberian Chains (Jiménez-Sánchez 2009, 2010; Jiménez-Sánchez et al. 2010) and the Sardinian occurrences (Conti 1990), and it is only surpassed in the Mediterranean Province by the occurrences studied in the Montagne Noire (Ernst \& Key 2007). 


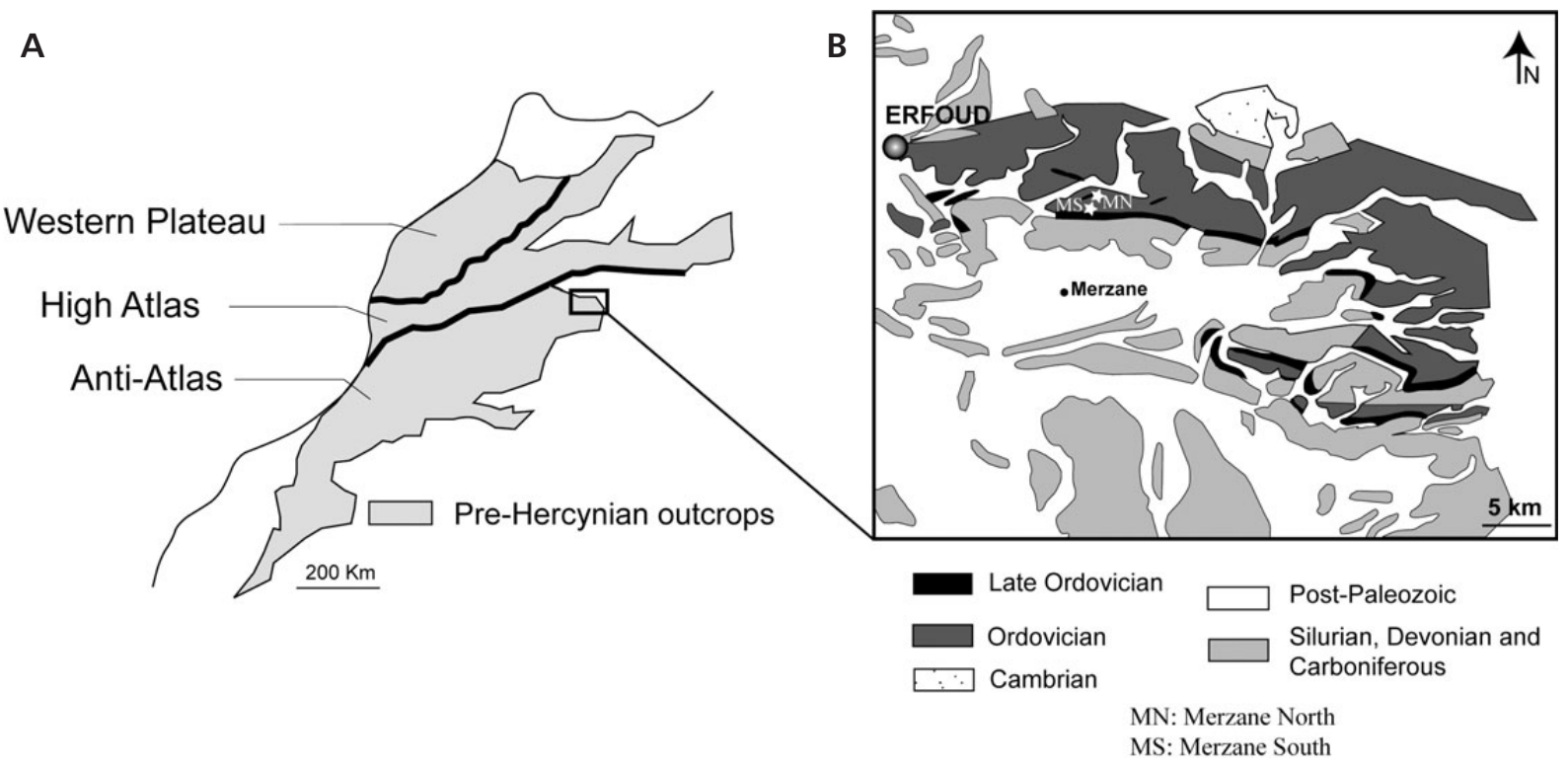

Figure 1. A - schematic geological map of the eastern area of Erfoud (Anti-Atlas, Morocco). $\bullet$ B - location of the studied stratigraphic section. Taken from Jiménez-Sánchez et al. (2015).

Recent studies on the bryozoans of the late Katian Khabt-el-Hajar Formation (Jiménez-Sánchez et al. 2015a, b), have identified 21 species of 12 trepostomate genera adapted to marly substrates of lower offshore environments, close to the Antarctic Polar Circle. Many of these species display significantly larger body sizes than congeneric species from lower latitudes, and several of them, based on their autozooecial sizes, may be examples of polar gigantism. At the moment new bryozoans are being studied from the same Khabt-el-Hajar Formation, representing shallower environments than those previously collected. The studied horizons represent storm-induced deposits of upper offshore environments, as well as high-energy deposits typical of a shore face environment. Analysis of the bryozoan fauna has resulted in the addition of another 15 species of 13 genera, of which 10 have not been previously identified. Furthermore, genera assigned as Fenestrata and Cryptostomata have not been recognised in former studies of the region. This large number of bryozoans, now established from a reduced area of the Moroccan Anti-Atlas, has allowed reconsidering the palaeobiogeographic relationships of the region within the temperate-to-cool water Mediterranean Province during moments previous to the Hirnantian glaciation.

\section{Geographical and geological setting}

Merzane North (MN) and Merzane South (MS) are two studied sections near the locality of Erfoud, in the easternmost edge of the Moroccan Anti-Atlas (Fig. 1). During the Lower Palaeozoic the Erfoud area corresponded to a mixed carbonate-siliciclastic platform with sharp lateral boundaries and is considered as an isolated platform (El Maazouz \& Hamoumi 2007). It is represented by the Khabt-el-Hajar Formation (Destombes et al. 1985), consisting of two mixed siliciclastic limestone units separated by a mixed marl-limestone unit. A preliminary sedimentological and stratigraphical study of the succession was presented by Meddour et al. (2010), and a more detailed stratigraphical and sedimentological description can be found in Jiménez-Sánchez et al. (2015a). The studied bryozoans have been collected from three different horizons (MN4, MS1 and MS5), corresponding to the three sedimentary units described in the latter paper (Figs 2 and 3) and referred to above. Carbonate productivity was not laterally persistent in the eastern Anti-Atlas, as shown by Alvaro et al. (2007). In the Tskaouine and Gaiz Jebels of the Alnif area (Alvaro et al. 2007) and in the Western Tafilalt domain (El Maazouz \& Hamoumi 2007) a siliciclastic-dominated platform records low activity of carbonate factories. These were known to be intensive in the Erfoud area as indicated by the bryozoan-dominated limestones of the late Katian Khabt-el-Hajar Formation.

\section{Sedimentological patterns}

The first unit (Unit 1; Fig. 2) of the bryozoan-rich Khabtel-Hajar Formation overlaps the sandstones of the Upper Tiouririne Formation and is up to $40 \mathrm{~m}$ thick. Its basal part is characterised by mixed siliciclastic-limestone layers of several dm thick showing an erosional base, stacked inversely to normal graded $\mathrm{cm}$ to dm-thick bioclastic accumula- 

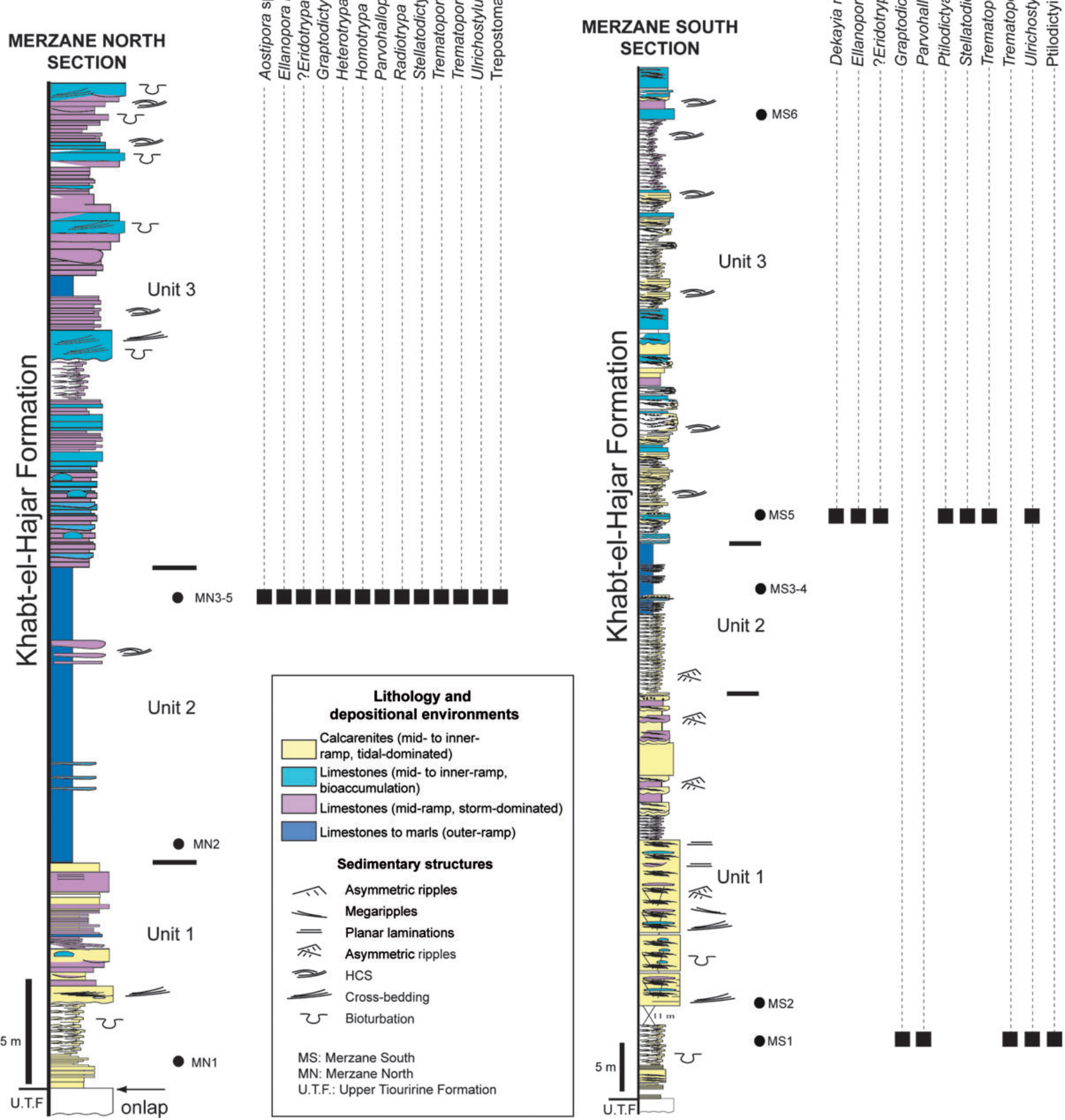

Figure 2. Stratigraphic log and distribution of the studied taxa in the Merzane North and Merzane South Sections. For the geographical location of horizons 3-5 (MN 3-5) in Merzane North Section see Jiménez-Sánchez et al. (2015), fig. 3.1.

tions composed of bryozoans and echinoderms and corresponds to storm-induced deposits of an upper offshore environment (horizon MS1). It passes upward to mixed limestone-siliciclastic sediments characterised by bidirec-

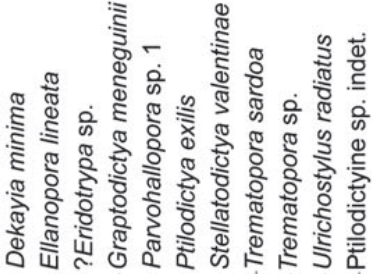


Table 1. Summary of the statistical analysis of Enallopora lineata Boulange, 1963, including: observed range (Or), mean value (X), standard deviation (SD), total number of measurements $(\mathrm{Nm})$, and number of fragments on which measurements have been taken (Nsp). All measurements in $\mathrm{mm}$.

\begin{tabular}{lcccrr}
\hline Character & Or & X & SD & Nm & Nsp \\
\hline Branch minimum diameter & $0.32-1.00$ & 0.59 & 0.21 & 9 & 9 \\
Extrazooecial skeleton thickness & $0.037-0.225$ & 0.112 & 0.047 & 43 & 17 \\
Pores diameter & $0.025-0.050$ & 0.039 & 0.009 & 9 & 3 \\
Zooecial minimum diameter & $0.09-0.17$ & 0.14 & 0.02 & 18 & 6 \\
Zooecial internal wall thickness & $0.010-0.050$ & 0.021 & 0.010 & 28 & 14 \\
$\begin{array}{l}\text { Zooecial minimum diameter in } \\
\text { endozone }\end{array}$ & $0.07-0.15$ & 0.11 & 0.02 & 20 & 9 \\
Zooecial spacing along branch & $0.50-0.65$ & 0.60 & 0.05 & 9 & 3 \\
\hline
\end{tabular}

$15 \mathrm{~m}$ thick both at the Merzane North and Merzane South sections. It is characterised by $\mathrm{cm}$-thick inversely graded bioclastic units with an erosional base (horizon MN4) embedded in marls. These reworked bioclastic units are considered as tempestites deposited in upper offshore environments. The marls are devoided of storm-induced deposits, showing complete bryozoans studied in JiménezSánchez et al. (2015a, b), and are interpreted as deposits of lower offshore environments. The third unit (Unit 3) is composed of pluri-dm to m-thick mixed siliciclastic-limestone layers (horizon MS5). Storm-induced deposits of upper offshore environment characterise this unit at Merzane North whereas at Merzane South it shows trough cross-beddings, thickening and fining upward succession, ripple marks and occasional storm-induced deposits (SCS - Swaley-crosslaminations) corresponding to high-energy mixed siliciclastic-limestone megaripples, deposited in a shoreface environment. The three horizons studied here, MN4, MS1, and MS5 correspond, therefore, to high-energy environments in which bryozoans with different degrees of fragmentation and transport were accumulated, most of them showing considerable superficial mechanical erosion.

\section{Systematic palaeontology}

Twenty-three thin sections with a total of 77 specimens have been studied in this systematic work using a transmitted light petrographic microscope. The measurements have been taken from the thin sections, either directly through the microscope with micrometer or from scaled photographs. In the following descriptions all average are mean values. Material described here is housed in the Museo de Ciencias Naturales of the University of Zaragoza (Spain) with catalogue numbers MPZ 2014/X and MPZ 2015/X, where " $X$ " is the identification number for each specimen. These numbers appear in the description of the species. In Fig. 2 is shown the stratigraphic distribution and horizon where each taxon was collected.
Class Stenolaemata Borg, 1926

Superorder Palaeostomata Ma et al., 2014

Order Fenestrata Astrova \& Morozova, 1956

Suborder Phylloporina Lavrentjeva, 1979

Family Enalloporidae Lavrentjeva, 1985

\section{Genus Enallopora d'Orbigny, 1850}

Type species. - Enallopora perantiqua (Hall, 1847). Caradoc (Upper Ordovician) of Middleville, Herkimer County (New York, U.S.A.).

Diagnosis. - Following Ernst \& Carrera (2012) Enallopora is characterized by having branched colonies dichotomously divided and not linked by either anastomoses or dissepiments; zooecia arranged in two or four longitudinal rows; median keel absent or poorly developed, and without spine or nodes. Zooecia consist of large tubes originating from and extending along planar wall of branch axial mid-plane. Zooecial apertures oval to rounded, often surrounded by small nodes. Peristome complete and long. Reverse and axial walls having microgranular structure and interzooecial skeleton finely laminated. Exozonal tubes present both to obverse and reverse surface, with rounded or oval openings.

Occurrence. - Middle Ordovician to Lower Silurian of North and South America, Europe, North Africa (Morocco) and India.

\section{Enallopora lineata Boulange, 1963}

Figure 3A, B, Table 1

1963 Enallopora lineata Boulange; Boulange, pp. 39-40, text-figs $5 \mathrm{a}, \mathrm{b}$.

Material. - MPZ 2014/494-510.

Description. - Branched colonies with an average minimum branch diameter of $0.59 \mathrm{~mm}$. Zooecia budding from a central axis in two stages of two paired rows divided by a vertical lamina; in proximal part zooecia growth parallel to branch, but in distal part they sharply bend to become nearly perpendicular to zoarial surface. Zooecia quadrangular to round in endozone with an average diameter of $0.11 \mathrm{~mm}$ and separated by an internal wall of an average thickness of $0.021 \mathrm{~mm}$ with granular microstructure. Zooecial aperture oval in shape, sometime rounded, with a minimum average diameter of $0.14 \mathrm{~mm}$; open to the obverse side and arranged in longitudinal rows, with spacing between them of $0.60 \mathrm{~mm}$ on average, measured longitudinally; apertures surrounded by a peristome with laminated microstructure. Extrazooecial skeleton thick ( $0.112 \mathrm{~mm}$ on average), with 

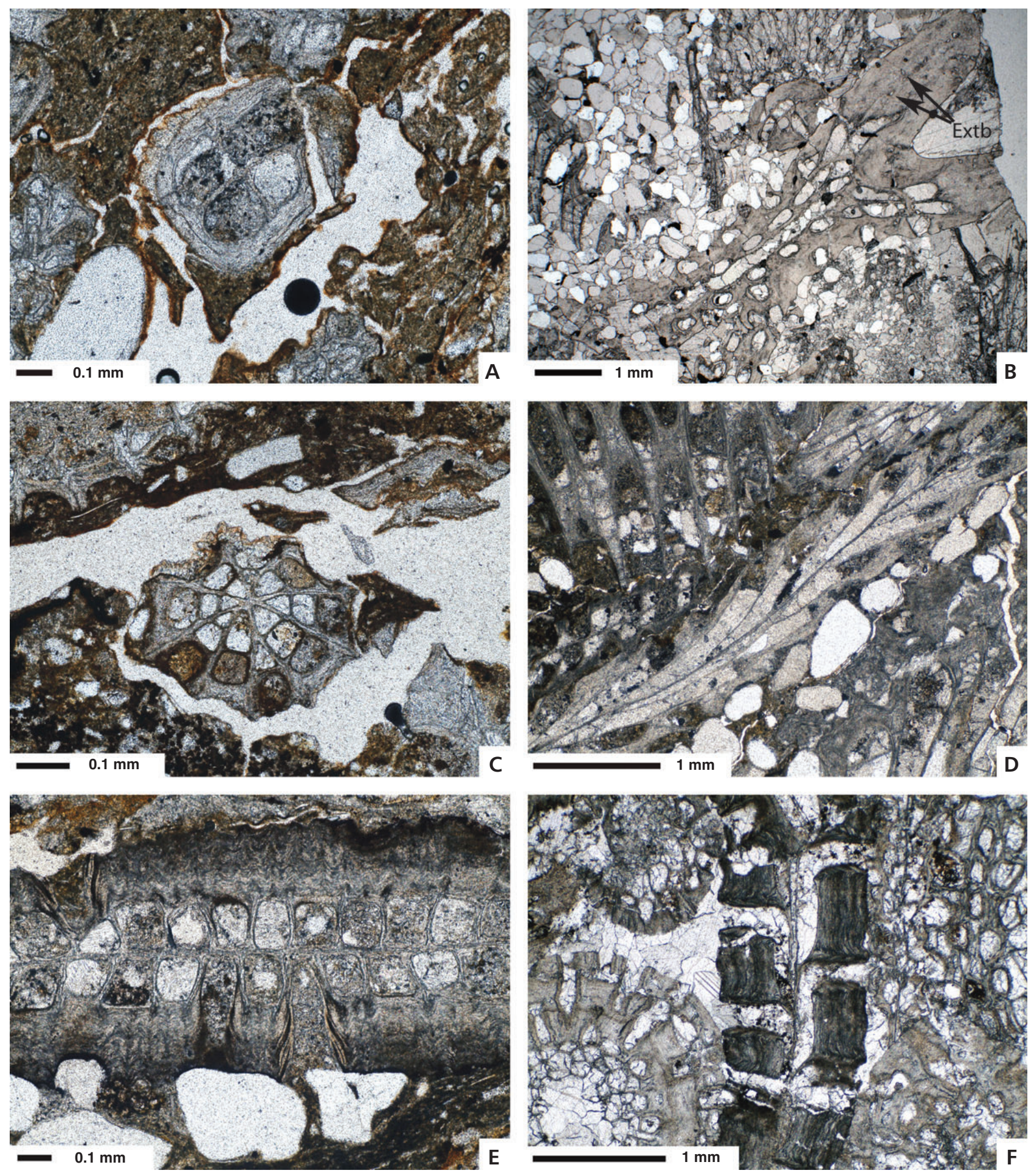

Figure 3. A, B - Enallopora lineata Boulange, 1963; A - transversal section of specimen MPZ 2014/494 showing quadrangular to round autozooecia in endozone; B - inclined section of specimen MPZ 2014/508 showing exozonal tubes (Extb). C , D - Ulrichostylus radiatus Conti, 1990; C - transversal section of specimen MPZ 2014/511 showing triangular autozooecia in endozone and elliptical autozooecia in exozone; D - longitudinal section of specimen MPZ 2014/517 showing the lineal axis. • E, F - Graptodictya meneghinii (Vinassa de Regny, 1942); E - transversal section of specimen MPZ 2014/526 showing mesotheca, quadrangular autozooecia in endozone and thick laminated and crinkled extrazooecial skeleton; F-longitudinal section of specimen MPZ 2014/531. Specimens MPZ 2014/494, 511, 517 and 526 from horizon MN4; specimen MPZ 2014/531 from horizon MS1; and specimen MPZ 2014/508 from horizon MS5. 
Table 2. Summary of the statistical analysis of Ulrichostylus radiatus Conti, 1990. Abbreviations as in Table 1.

\begin{tabular}{lccccc}
\hline Character & Or & X & SD & Nm & Nsp \\
\hline $\begin{array}{l}\text { Autozooecial angle with central } \\
\text { axis }\end{array}$ & $10.5^{\circ}-19.7^{\circ}$ & $14.7^{\circ}$ & 4.1 & 5 & 1 \\
$\begin{array}{l}\text { Autozooecial angle with zoarial } \\
\text { surface }\end{array}$ & $19.0^{\circ}-61.1^{\circ}$ & $36.5^{\circ}$ & 17.2 & 16 & 3 \\
$\begin{array}{l}\text { Autozooecial aperture minimum } \\
\text { diameter }\end{array}$ & $0.12-0.15$ & 0.14 & 0.01 & 4 & 1 \\
$\begin{array}{l}\text { Autozooecial distal wall } \\
\text { thickness in exozone }\end{array}$ & $0.030-0.075$ & 0.049 & 0.014 & 13 & 6 \\
$\begin{array}{l}\text { Autozooecial minimum diameter } \\
\text { in exozone }\end{array}$ & $0.05-0.11$ & 0.08 & 0.01 & 20 & 8 \\
$\begin{array}{l}\text { Autozooecial rows } \\
\begin{array}{l}\text { Autozooecial wall thickness } \\
\text { in endozone }\end{array}\end{array}$ & $0.009-0.020$ & 0.014 & 0.004 & 21 & 8 \\
$\begin{array}{l}\text { Branch minimum diameter } \\
\begin{array}{l}\text { Endozone minimum diameter } \\
\hline\end{array}\end{array}$ & $0.47-1.17$ & 0.80 & 0.25 & 10 & 10 \\
\hline
\end{tabular}

laminated microstructure, and crossed by numerous exozonal tubes, oval to rounded in shape and with an average diameter of $0.039 \mathrm{~mm}$, present in both obverse and reverse sides.

Remarks. - The shape of the colonies with branches dichotomously divided and not linked by either anastomoses or dissepiments; the zooecia arranged in longitudinal rows; the absence of median keel; the zooecial tubes originating from and extending along planar wall of branch axial mid-plane, the oval to rounded zooecial apertures and the presence of peristome in the apertures; the reverse and axial walls with granular microstructure and the interzooecial skeleton finely laminated; and finally, the exozonal tubes present in both obverse and reverse surface, with rounded or oval openings, are the characters that have allowed us to include this material in the genus Enallopora.

This material has been assigned to Enallopora lineata defined by Boulange (1963) in the Upper Ordovician (Ashgill) of the Grange du Pin (Hérault, France) because the specimens are quantitatively and qualitatively very similar to this species. They share the way in which zooecia grow from the median wall, recumbent in the proximal part and forming a sharp angle with the external surface in the distal one; the zooecial apertures arranged in four longitudinal rows with the lateral adjacent apertures at different heights; the random distribution of the exozonal tubes in the obverse side; the minimum diameter of branch $(0.59 \mathrm{~mm}$ in Moroccan material on average $v s 0.50 \mathrm{~mm}$ in the French ones); and the minimum zooecial diameter (a range of $0.09-0.17 \mathrm{~mm}$ in Moroccan material vs $0.14-0.17 \mathrm{~mm}$ in the French ones).

Enallopora lineata can be distinguished from E. exiqua (Ulrich, 1890) described by this author in the Upper Ordovician of North America and by Ernst \& Carrera (2012) in the Upper Ordovician of the Argentinean Precordillera because the latter species has much smaller branch and zooecial diameters (a range of $0.27-0.47 \mathrm{~mm}$ in E. exiqua branch diameter vs $0.32-1.00 \mathrm{~mm}$ in E. lineata described in Morocco and a range of $0.05-0.10 \mathrm{~mm}$ in E. exiqua zooecial diameter $v s$ $0.09-0.17 \mathrm{~mm}$ in E. lineata described in Morocco) and the distribution of the exozonal tubes is more regular than in E. lineata.

Occurrence. - This species has been described in the Ashgill (Upper Ordovician) of the Grange du Pin (Hérault, France) and in the Khabt-el-Hajar Formation, horizons MN4 and MS5, in the northeastern Moroccan Anti-Atlas (Upper Ordovician, upper Katian).

Order Cryptostomata Vine, 1884

Suborder Rhabdomesina Astrova \& Morozova, 1956

Family Arthrostylidae Ulrich, 1882

\section{Genus Ulrichostylus Bassler, 1952}

Type species. - Helopora divaricatus Ulrich, 1886. Decorah Shale, Middle Ordovician of Minneapolis (USA).

Diagnosis. - Following Ernst \& Key (2007) Ulrichostylus is characterized by having dendroid to unbranched colonies. Autozooecial apertures arranged in 6-8 longitudinal rows, separated by prominent longitudinal ridges. Axial region formed by a lineal axis, where autozooecia budding with an angle of $20^{\circ}-40^{\circ}$. Autozooecial cross-section triangular in endozone, becoming elliptical in exozone, forming an angle of $60^{\circ}-70^{\circ}$ with colony surface. Diaphragms rare or absent. Exozonal material well developed. Mesozooecia absent. Paurostyles scattered, weakly developed.

Remarks. - Blake (1983) revised the genus Ulrichostylus and reduced its number of autozooecial rows from eight or more, as was considered by Bassler (1952), to between six and eight. Conti (1990) included Ulrichostylus radiatus with twelve autozooecial rows in the genus Ulrichostylus. Ernst \& Key (2007) considered again 6 to 8 as the diagnostic number of autozooecial longitudinal rows. We follow Ernst \& Key's (2007) diagnosis, but accept the increase in the number of autozooecial rows introduced by Conti (1990).

Occurrence. - Middle to Upper Ordovician of North America, Europe and North Africa (Morocco).

\section{Ulrichostylus radiatus Conti, 1990}

Figure 3C, D, Table 2

1990 Ulrichostylus radiatus Conti; Conti, p. 116, pl. 21, figs $7-12$. 
2007 Ulrichostylus radiatus Conti, 1990. - Ernst \& Key, p. 401, pl. 15, figs $1-4$.

2007 Ulrichostylus sp. Conti, 1990. - Jiménez-Sánchez et al., p. 685, fig. 8.2.

2009 Ulrichostylus radiatus Conti, 1990. - JiménezSánchez, pp. 698-699, fig. 10d, e.

Material. - MPZ 2014/511-525.

Description. - Zoarium ramose; individual branches subpolygonal in cross-section with an average diameter of $0.80 \mathrm{~mm}$. Autozooecial apertures large $(0.14 \mathrm{~mm}$ of average diameter) and arranged in longitudinal rows (an average of 11 per branch), separated in this direction by a prominent ridge. Axial region formed by a well-defined linear axis, with autozooecia arranged radially around it. Endozone with an average diameter of $0.31 \mathrm{~mm}$, with triangular autozooecia growing from the central axis with an average angle of $14.7^{\circ}$. In exozone autozooecia elliptical in crosssection with an average minimum diameter of $0.082 \mathrm{~mm}$ and reaching zoarial surface with an average angle of $36.5^{\circ}$. In endozone autozooecial walls hyaline, continuous from the central axis, with an average thickness of $0.014 \mathrm{~mm}$; in exozone walls composed of a hyaline layer, sheathed by outer laminated skeleton; autozooecial distal wall in exozone $0.049 \mathrm{~mm}$ of average thickness.

Remarks. - The arrangement of autozooecial apertures in longitudinal rows separated by prominent ridges; the presence of the central axis with autozooecial rows around it; the shape of autozooecial cross-section both in endozone and exozone; as well as the absence of autozooecial diaphragms and mesozooecia have allowed us to assign this material to Ulrichostylus.

These specimens fit well with Ulrichostylus radiatus as was described by Conti (1990) in the Upper Ordovician type material from Sardinia (Italy), by Ernst \& Key (2007) in the Upper Ordovician from the Montagne Noire (France) and by Jiménez-Sánchez (2009) in the Upper Ordovician of the Iberian Chains (Spain). The Moroccan material shares with them the absence of autozooecial diaphragms and acanthostyles, as well as a similar number of autozooecial rows and similar autozooecial diameter; consequently these specimens are included in $U$. radiatus.

Ulrichostylus radiatus is similar to U. costatus Lobdell, 1992, but the former species has more autozooecial longitudinal rows (7-14 in $U$. radiatus described in Morocco vs $7-8$ in $U$. costatus) and smaller autozooecial apertures (0.12-0.15 mm in Moroccan Ulrichostylus vs $0.10-0.20 \mathrm{~mm}$ in $U$. costatus).

Occurrence. - This species has been described in materials from the Upper Ordovician (upper Katian) of: the Maciurru and Punta S'Argiola Members of the Domus-Novas For- mation (Sardinia, Italy), the carbonate and clastic sequence from the Montagne Noire (France), the La Peña Member (layers 4, 6-9, 11 and 12) of the Valdelaparra section (Fombuena, Spain), and the Khabt-el-Hajar Formation in horizons MN4, MS1 and MS5, northeastern Moroccan Anti-Atlas (Morocco).

Suborder Ptilodictyina Zittel, 1880

Family Ptilodictyidae Zittel, 1880

\section{Genus Graptodictya (Ulrich, 1882)}

Type species. - Graptodictya perelegans (Ulrich, 1878). Waynesville Shale (Upper Ordovician of Ohio, U.S.A.).

Diagnosis. - Following Ernst \& Key (2007) the genus Graptodictya is characterized by having bifoliate branching colonies; mesotheca slightly sinuous in longitudinal section and sometime zigzag in transverse ones; in the exozone autozooecia form an angle of $80^{\circ}-90^{\circ}$ with mesotheca; pustules abundant in the autozooecial boundaries, in the exozonal walls and in the extrazooecial skeleton; autozooecial cross-section elliptical to oval; superior hemisepta common, generally short and blunt and curving proximally; exilazooecia and monticules absent to rare; extrazooecial skeleton laminate, commonly crinkled forming longitudinal striae between autozooecia, along colonial margins and proximal parts of colonies.

Occurrence. - Middle Ordovician to Lower Silurian of Europe, North America and North Africa (Morocco).

\section{Graptodictya meneghinii (Vinassa de Regny, 1942)} Figures 3E, F, 4A, Table 3

1942 Pachydictya meneghinii Vinassa de Regny; Vinassa de Regny, pp. 1030-1031, pl. 1, figs 6-8.

1942 Graptodictya sp. Vinassa de Regny, 1942. - Vinassa de Regny, p. 1030, pl. 1, figs 4, 5.

1942 Pachydictya (?) sardoa Vinassa de Regny, 1942. Vinassa de Regny, p. 1031, pl. 1, fig. 11.

1988 Graptodictya sp. (Vinassa de Regny, 1942). - Conti \& Serpagli, p. 143, pl. 11, fig. 5, pl. 12, figs 2, 3.

1990 Graptodictya meneghinii (Vinassa de Regny, 1942). - Conti, pp. 113-114, pl. 20, figs 4-7.

2007 Graptodictya meneghinii (Vinassa de Regny, 1942). - Ernst \& Key, p. 50, pl. 17, fig. 15, pl. 18, figs 1-3.

2007 Graptodictya sp. (Vinassa de Regny, 1942). Jiménez-Sánchez et al., p. 685, figs 7.5, 7.6.

2009 Graptodictya cf. meneghinii (Vinassa de Regny, 1942). - Jiménez-Sánchez, pp. 690-692, fig. 3A, B, text-figs 4,5 . 
Table 3. Summary of the statistical analysis of Graptodictya meneghinii (Vinassa de Regny, 1942). Abbreviations as in Table 1.

\begin{tabular}{|c|c|c|c|c|c|}
\hline Character & Or & $\mathrm{X}$ & SD & $\mathrm{Nm}$ & Nsp \\
\hline $\begin{array}{l}\text { Autozooecial angle with } \\
\text { mesotheca }\end{array}$ & $29.0^{\circ}-52.0^{\circ}$ & $40.1^{\circ}$ & 9.3 & 7 & 2 \\
\hline $\begin{array}{l}\text { Autozooecial angle with zoarial } \\
\text { surface }\end{array}$ & $75.5^{\circ}-89.5^{\circ}$ & $83.7^{\circ}$ & 5.4 & 6 & 2 \\
\hline $\begin{array}{l}\text { Autozooecial aperture maximum } \\
\text { diameter }\end{array}$ & $0.19-0.30$ & 0.23 & 0.03 & 16 & 3 \\
\hline $\begin{array}{l}\text { Autozooecial aperture minimum } \\
\text { diameter }\end{array}$ & $0.09-0.17$ & 0.11 & 0.02 & 17 & 3 \\
\hline $\begin{array}{l}\text { Autozooecial diameter } \\
\text { in endozone }\end{array}$ & $0.09-0.15$ & 0.12 & 0.01 & 24 & 3 \\
\hline $\begin{array}{l}\text { Autozooecial spacing along } \\
\text { branch }\end{array}$ & $0.50-0.82$ & 0.67 & 0.10 & 17 & 3 \\
\hline Autozooecial spacing diagonally & $0.37-0.50$ & 0.43 & 0.05 & 13 & 3 \\
\hline $\begin{array}{l}\text { Autozooecial wall thickness } \\
\text { in endozone }\end{array}$ & $0.008-0.030$ & 0.014 & 0.006 & 19 & 3 \\
\hline $\begin{array}{l}\text { Autozooecial wall thickness } \\
\text { in exozone }\end{array}$ & $0.025-0.062$ & 0.043 & 0.012 & 11 & 3 \\
\hline Brach thickness & $0.70-0.90$ & 0.76 & 0.08 & 5 & 5 \\
\hline Endozone thickness & $0.11-0.19$ & 0.13 & 0.02 & 16 & 4 \\
\hline Exozone thickness & $0.14-0.35$ & 0.24 & 0.05 & 17 & 5 \\
\hline Mesotheca thickness & $0.012-0.037$ & 0.021 & 0.008 & 15 & 5 \\
\hline
\end{tabular}

Material. - MPZ 2014/526-535.

Description. - Bifoliate branch colonies with individual branches of $0.76 \mathrm{~mm}$ of average thickness. Autozooecia forming an initial angle of $40^{\circ}$ with mesotheca, then they bend and grow parallel to mesotheca in endozone; autozooecial cross-section quadrangular to subcircular in endozone with an average diameter of $0.12 \mathrm{~mm}$; in exozone autozooecia sharply bend forming an average angle of $84^{\circ}$ with zoarial surface. Autozooecial apertures arranged in longitudinal rows with lateral adjacent apertures at different heights forming a diagonal pattern; oval to elliptical in shape with a minimum and maximum average diameter of $0.11 \mathrm{~mm}$ and $0.23 \mathrm{~mm}$, respectively, and spacing $0.67 \mathrm{~mm}$ measured longitudinally and $0.43 \mathrm{~mm}$ measured diagonally. Autozooecial wall thin in endozone $(0.014 \mathrm{~mm}$ of average thickness) and thicker in exozone $(0.043 \mathrm{~mm}$ of average thickness) with laminated microstructure. Autozooecial aperture separated by a thick laminated and crinkled extrazooecial skeleton forming longitudinal striae between autozooecial apertures. Superior hemisepta present in distal part of autozooecia, short and blunt. Mesotheca lightly sinuous in longitudinal section and generally straight in transversal section, composed by two external laminated layer and a thin central one with granular microstructure; three-laminar mesotheca have a total thickness of $0.021 \mathrm{~mm}$ on average.

Remarks. - Material described here shares with the genus
Graptodictya the bifoliate habit of growth; the shape of mesotheca, slightly sinuous in longitudinal section; the angle that autozooecia form with mesotheca both in endozone and exozone; the elliptical to oval shape of autozooecial apertures; the short and blunt shape of superior hemisepta; as well as the laminated and crinkled thick extrazooecial skeleton, forming longitudinal striae between autozooecia. So, this material is assigned to Graptodictya.

Moroccan specimens are morphologically closely related to G. meneghinii (Vinassa de Regny, 1942), as described by Conti (1990) in the Upper Ordovician of Sardinia, and by Ernst \& Key (2007) in the Upper Ordovician of Montagne Noire. They share the oval form of autozooecial apertures and its width $(0.09-0.17 \mathrm{~mm}$ in Moroccan material, $0.08-0.16 \mathrm{~mm}$ in French material and $0.061-0.15 \mathrm{~mm}$ in Italian material) and the spacing of apertures along branch $(0.50-0.82 \mathrm{~mm}$ in Moroccan material and $0.51-0.61 \mathrm{~mm}$ in the French one); the subpolygonal cross-section of autozooecia in endozone; the sharp autozooecial angle with the zoarial surface (always within the range of $75^{\circ}-90^{\circ}$ ); the presence of short and blunt superior hemisepta; the presence of a thick laminated and crinkled extrazooecial skeleton; as well as the form of mesotheca, slightly sinuous in longitudinal sections and straight in transversal ones. So, these Moroccan specimens have been assigned to G. meneghinii.

Graptodictya lahgdadensis, Termier \& Termier, 1950 was described in the basal mixed siliciclastic-carbonate unit of the Khabt-el-Hajar Formation (Jiménez-Sánchez et al. 2015a). No detailed description of this species is available, but in the hand-made drawings provided by Termier \& Termier (1950) it is easy to distinguish G. lahgdadensis from $G$. meneghinii since the former has autozooecial diaphragms and sharp inferior hemisepta are present.

Occurrence. - This species has been described in the Ashgill (Upper Ordovician) of the Grange du Pin (Hérault, France); in the units $c$ and $e$ of the Upper Caradoc-Lower Ashgill (Upper Ordovician) of Sardinia (Italy) and in the Khabt-el-Hajar Formation, horizons MN4 and MS1, in the northeastern Moroccan Anti-Atlas (Upper Ordovician, upper Katian).

\section{Genus Ptilodictya Lonsdale, 1839}

Type species. - Ptilodictya lanceolata (Goldfuss, 1829). Wenlock (Silurian) of Great Britain.

Diagnosis. - Following Ernst \& Carrera (2012) Ptilodictya is characterized by having colonies lancet or belt in shape; straight mesotheca, locally in zigzag, and without median rods; straight, tubular and long autozooecia, subrectangular to subhexagonal in endozone and commonly subrectangular 
Table 4. Summary of the statistical analysis of Ptilodictya exilis Lavrentjeva, 1993. Abbreviations as in Table 1.

\begin{tabular}{lccccc}
\hline Character & Or & X & SD & Nm & Nsp \\
\hline $\begin{array}{l}\text { Autozooecial aperture maximum } \\
\text { diameter }\end{array}$ & $0.29-0.37$ & 0.34 & 0.03 & 12 & 1 \\
$\begin{array}{l}\text { Autozooecial aperture minimum } \\
\text { diameter }\end{array}$ & $0.10-0.14$ & 0.12 & 0.01 & 12 & 1 \\
$\begin{array}{l}\text { Autozooecial spacing along } \\
\text { branch }\end{array}$ & $0.37-0.45$ & 0.41 & 0.03 & 10 & 1 \\
$\begin{array}{l}\text { Autozooecial spacing laterally } \\
\begin{array}{l}\text { Autozooecial wall thickness in } \\
\text { endozone }\end{array}\end{array}$ & $0.12-0.20$ & 0.17 & 0.02 & 10 & 1 \\
\hline
\end{tabular}

in exozone, although oval form can be also present; autozooecial apertures arranged in longitudinal rows, separated by straight ridges; diaphragms absent; superior and inferior hemisepta as well as mural spines can be present; monticules flat to slightly raised and irregularly distributed.

Occurrence. - Middle Ordovician to Lower Devonian of North and South America, Europe, Siberia, Mongolia and India and Upper Ordovician of North Africa (Morocco).

\section{Ptilodictya exilis Lavrentjeva, 1993 (in Gorjunova \& Lavrentjeva 1993) Figure 4B, Table 4}

1993 Ptilodictya exilis Lavrentjeva; Lavrentjeva in Gorjunova \& Lavrentjeva, p. 68, pl. 10, fig. 4.

Material. - MPZ 2014/536.

Description. - Lancet bifoliate zoarium with maximum and minimum diameter unknown since no transversal section is available. Autozooecia apertures arranged in four longitudinal rows, separated by straight ridges, and spaced $0.41 \mathrm{~mm}$ longitudinally and $0.17 \mathrm{~mm}$ transversally (measured from centre to centre). Autozooecia cross-section subrectangular to oval in exozone, with a maximum and minimum average diameter of $0.34 \mathrm{~mm}$ and $0.12 \mathrm{~mm}$, respectively; trapezoidal shape in cross-section near mesotheca. In endozone autozooecia forming an angle of about $45^{\circ}$ with mesotheca, constant up to zoarial surface. Autozooecial wall $0.009 \mathrm{~mm}$ of average thickness in endozone. Diaphragms, hemisepta and mural spines absent. Mesotheca is destroyed by compaction, therefore its morphology is unknown.

Remarks. - The lancet shape of the zoarium with the autozooecial apertures arranged in longitudinal rows, separated by straight ridges; the trapezoid autozooecial cross-section in endozone as well as the subromboidal to oval shape in exozone; and the absence of diaphragms are characters pre- sent in this Moroccan zoarium that have allowed us to include it in Ptilodictya.

The material described here shares with Ptilodictya exilis Lavrentjeva (in Gorjunova \& Lavrentjeva, 1993), from the Caradoc (Upper Ordovician) of Estonia, the minimum diameter of autozooecial apertures $(0.10-0.14 \mathrm{~mm}$ in the Moroccan material and $0.10-0.13 \mathrm{~mm}$ in the Estonian one), the subrectangular to oval autozooecial cross-section in exozone and the constant angle formed by autozooecia from the mesotheca up to the zoarial surface. However, maximum autozooecial diameter is larger in Moroccan zoarium (0.29-0.37 mm vs 0.19-0.26 $\mathrm{mm}$ in the Estonian ones), but this difference in the diameter is largely caused by the inclined section of the Moroccan specimen. So, the Moroccan zoarium is assigned to $P$. exilis.

Occurrence. - This species has been described in the Caradoc (Jövi to Oandu stages: $\mathrm{D}_{\text {I-III }}$ ) of Estonia and in the Khabt-el-Hajar Formation in the horizon MS5, northeastern Moroccan Anti-Atlas (Upper Ordovician, upper Katian).

Family Rhinidictyidae Ulrich, 1893

\section{Genus Stellatodictya Gorjunova, 1993 (in Gorjunova \& Lavrentjeva 1993)}

Type species. - Stellatodictya plana Lavrentjeva in Gorjunova \& Lavrentjeva, 1993. Caradoc (Upper Ordovician) of northwestern Russia.

Diagnosis. - Following Ernst \& Key (2007) Stellatodictya is characterized by bifoliate colonies with flattened and ellipsoidal cross-section branches. Mesotheca straight and with median rods. Autozooecia growth parallel to mesotheca and strongly bend in internal exozone, without diaphragms or hemisepta. Autozooecial aperture rounded to oval with peristomes, arranged in diagonal rows. Interspace between autozooecia consisting of vesicular tissue covered by a thick calcitic laminar skeleton. Vesicles large, having polygonal-box shape and curved roofs. Stellatopores developed in calcitic laminar skeleton, adjoined to autozooecia and surrounding them in a single row. Without maculae.

Occurrence. - Upper Ordovician of northwestern Russia, Estonia, northern India, southern France and Morocco.

Stellatodictya valentinae Ernst \& Key, 2007 Figure 4C-E, Table 5

2007 Stellatodictya valentinae Ernst \& Key; Ernst \& Key, pp. 47-49, pl. 16, figs 12, 13, pl. 17, figs 1-6. 
Table 5. Summary of the statistical analysis of Stellatodictya valentinae Ernst \& Key, 2007. Abbreviations as in Table 1.

\begin{tabular}{|c|c|c|c|c|c|}
\hline Character & Or & $\mathrm{X}$ & SD & $\mathrm{Nm}$ & Nsp \\
\hline $\begin{array}{l}\text { Autozooecial angle with zoarial } \\
\text { surface }\end{array}$ & $72.0^{\circ}-86.0^{\circ}$ & $78.5^{\circ}$ & 4.8 & 13 & 3 \\
\hline $\begin{array}{l}\text { Autozooecial aperture minimum } \\
\text { diameter }\end{array}$ & $0.08-0.15$ & 0.10 & 0.02 & 68 & 9 \\
\hline Autozooecia/mm $\mathrm{m}^{2}$ & $8.0-15.0$ & 11.2 & 2.0 & 12 & 6 \\
\hline $\begin{array}{l}\text { Autozooecial aperture spacing } \\
\text { diagonally }\end{array}$ & $0.20-0.45$ & 0.32 & 0.06 & 24 & 5 \\
\hline $\begin{array}{l}\text { Autozooecial wall thickness } \\
\text { in exozone }\end{array}$ & $0.012-0.050$ & 0.026 & 0.009 & 33 & 8 \\
\hline Extrazooecial skeleton thickness & $0.19-0.35$ & 0.26 & 0.05 & 17 & 4 \\
\hline $\begin{array}{l}\text { Number of autozooecial rows } \\
\text { in } 5 \mathrm{~mm} \text { diagonally measured }\end{array}$ & $14-18$ & 16 & 2 & 3 & 1 \\
\hline Stellathostyles diameter & $0.025-0.100$ & 0.053 & 0.015 & 31 & 7 \\
\hline Stellathostyles $/ \mathrm{mm}^{2}$ & $4-13$ & 9 & 3 & 9 & 4 \\
\hline
\end{tabular}

Table 6. Summary of the statistical analysis of Ptilodictyine sp. indet. Abbreviations as in Table 1.

\begin{tabular}{|c|c|c|c|c|c|}
\hline Character & Or & $\mathrm{X}$ & SD & $\mathrm{Nm}$ & Nsp \\
\hline $\begin{array}{l}\text { Autozooecial angle with } \\
\text { mesotheca }\end{array}$ & $23^{\circ}-25^{\circ}$ & $24^{\circ}$ & 1 & 2 & 1 \\
\hline $\begin{array}{l}\text { Autozooecial angle with zoarial } \\
\text { surface }\end{array}$ & $52^{\circ}-67^{\circ}$ & $57^{\circ}$ & 9 & 3 & 1 \\
\hline Autozooecial diameter & $0.10-0.15$ & 0.12 & 0.02 & 5 & 1 \\
\hline $\begin{array}{l}\text { Autozooecial spacing along } \\
\text { branch }\end{array}$ & $0.45-0.57$ & 0.51 & 0.06 & 3 & 1 \\
\hline Autozooecial wall thickness & $0.025-0.062$ & 0.037 & 0.015 & 5 & 1 \\
\hline Mural styles diameter & $0.012-0.030$ & 0.023 & 0.006 & 7 & 1 \\
\hline
\end{tabular}

Material. - MPZ 2014/537-545.

Description. - Bifoliate branching colonies with maximum and minimum branch diameter unknown since no transversal section has been obtained. Autozooecial apertures rounded to oval with an average diameter of $0.10 \mathrm{~mm}$ and an average of 11.2 autozooecia $/ \mathrm{mm}^{2}$; arranged in diagonal rows with an average spacing of $0.32 \mathrm{~mm}$ between autozooecial apertures and 16 rows $/ 5 \mathrm{~mm}$ in diagonal direction; autozooecia growing recumbent on mesotheca; at base of exozone they bend sharply forming an average angle of $78.5^{\circ}$ with zoarial surface; autozooecial wall thin in endozone, without recognizable microstructure, at base of exozone wall thickens until reaching $0.026 \mathrm{~mm}$ of average thickness, with a laminated microstructure; autozooecial diaphragms and hemisepta absent. Vesicles developed at base of exozone, having shape of quadrangular to rectangular boxes, with 1-2 rows of vesicles in longitudinal direction and 1-3 in horizontal direction; covered by calcitic laminated extrazooecial skeleton with an average thickness of $0.26 \mathrm{~mm}$. Stellathostyles large $(0.053 \mathrm{~mm}$ of average diameter) and abundant ( 9 stellathostyles $/ \mathrm{mm}^{2}$ ) and loca- ted in laminated extrazooecial skeleton; they are composed of a distinct light hyaline lumen with radially arranged rays, surrounded by sheaths. Macula absent.

Remarks. - The development of autozooecia, growing parallel to mesotheca and strongly bend at the base of exozone; the absence of diaphragms and hemisepta; the shape of autozooecial apertures and its arrangement in the zoarial surface; the presence of vesicular tissue between autozooecia, that is covered by a laminated skeleton; the presence of stellathostyles located in the laminated skeleton; as well as the absence of macula are diagnostic characters that have allowed us to assign this material in the genus Stellatodictya. These specimens fit well with Stellatodictya valentinae Ernst \& Key, 2007 as was described by the authors in the Upper Ordovician of the Montagne Noire (France), and accordingly they have been included in this species. They share, beside the diagnostic characters of the species, similar autozooecial diameter $(0.09-0.15 \mathrm{~mm}$ in the French material and $0.07-0.15 \mathrm{~mm}$ in the Moroccan material) and similar number of autozooecial rows measured in diagonal direction (15-19 rows $/ 5 \mathrm{~mm}$ in the French material and 14-18 rows $/ 5 \mathrm{~mm}$ in the Moroccan material). The most noticeable difference between both materials is in the size of stellathostyles, smaller in the French material (0.01-0.03 $\mathrm{mm}$ vs $0.02-0.10 \mathrm{~mm}$ in the Moroccan material).

Occurrence. - This species has been described in the Upper Caradoc-Lower Ashgill of Montagne Noire (southern France), and in the Khabt-el-Hajar Formation in horizons MN4 and MS5, northeastern Moroccan Anti-Atlas, (Upper Ordovician, upper Katian).

\section{Incertae sedis}

\section{Ptilodictyine sp. indet.}

Figure 4F, Table 6

Material. - MPZ 2014/546.

Description. - Branch colony apparently bifoliate and with unknown diameter. Autozooecia forming and initial angle of $24^{\circ}$ with mesotheca, then they lightly bend and grow parallel to mesotheca in endozone; in exozone autozooecia sharply bend forming an average angle of $57^{\circ}$ with zoarial surface. Autozooecial apertures apparently arranged in longitudinal rows, with a spacing of $0.51 \mathrm{~mm}$ along branch; autozooecial cross-section circular with an average diameter of $0.12 \mathrm{~mm}$. Autozooecial walls laminated, $0.037 \mathrm{~mm}$ of average thickness in exozone. Mural styles abundant, $0.023 \mathrm{~mm}$ of average diameter and placed, as longitudinal rows, in skeletal material separating adjacent autozooecial apertures. 

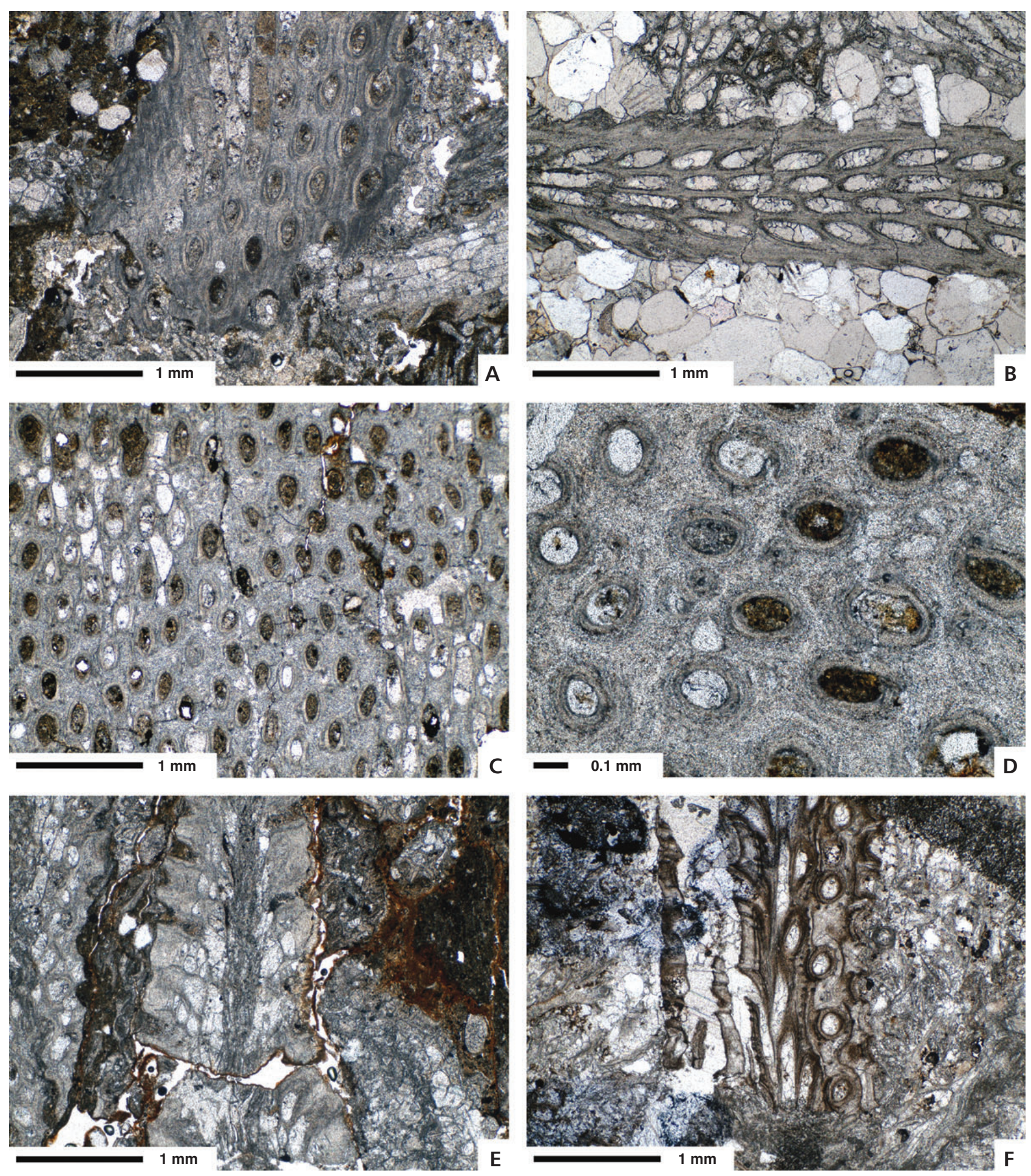

Figure 4. A - Graptodictya meneghinii (Vinassa de Regny, 1942), tangential section of specimen MPZ 2014/528. • B - Ptilodictya exilis Lavrentjeva, 1993, tangential section of specimen MPZ 2014/536. C C-E - Stellatodictya valentinae Ernst \& Key, 2007; C - tangential section of specimen MPZ 2014/540; D - detailed deep tangential section of specimen MPZ 2014/539 showing stellathostyles and vesicles in exozone; E - longitudinal section of specimen MPZ 2014/542 showing numerous vesicles in exozone. • F - Ptilodictyinae sp. indet., inclined section of specimen MPZ 2014/546 showing numerous mural styles in extrazooecial skeleton. Specimens MPZ 2014/528, 539, 540 and 542 from horizon MN4; specimen MPZ 2014/546 from horizon MS1; and specimen MPZ 2014/536 from horizon MS5. 
Table 7. Summary of the statistical analysis of Radiotrypa sp. Abbreviations as in Table 1.

\begin{tabular}{lccccc}
\hline Character & Or & X & SD & Nm & Nsp \\
\hline $\begin{array}{l}\text { Autozooecial angle with zoarial } \\
\text { surface }\end{array}$ & $38.0^{\circ}-71.0^{\circ}$ & $49.0^{\circ}$ & 13.1 & 5 & 1 \\
Autozooecial diameter & $0.10-0.14$ & 0.12 & 0.01 & 8 & 3 \\
$\begin{array}{l}\text { Autozooecial wall thickness } \\
\text { in endozone }\end{array}$ & $0.010-0.025$ & 0.016 & 0.004 & 19 & 3 \\
$\begin{array}{l}\text { Autozooecial wall thickness } \\
\text { in exozone }\end{array}$ & $0.030-0.060$ & 0.045 & 0.009 & 11 & 3 \\
$\begin{array}{l}\text { Branch diameter } \\
\text { Endozone diameter }\end{array}$ & $1.4-1.9$ & 1.7 & 0.2 & 3 & 3 \\
Exozone thickness & $1.00-1.10$ & 1.05 & 0.07 & 2 & 2 \\
\hline & $0.30-0.44$ & 0.38 & 0.06 & 4 & 2 \\
\hline
\end{tabular}

Remarks. - This specimen can be included in the suborder Ptilodictyina since it has a bifoliate zoarium and short autozooecia growing from mesotheca. However, the scarcity of observed characters has precluded us to propose a more accurate systematic classification and we left it in open nomenclature to the generic level.

Occurrence. - Ptilodictyine sp. indet. is known exclusively from the Khabt-el-Hajar Formation, horizon MS1, northeastern Moroccan Anti-Atlas (Upper Ordovician, upper Katian).

Order Trepostomata Ulrich, 1882

Suborder Amplexoporina Astrova, 1965

Family Amplexoporidae Miller, 1889

\section{Genus Radiotrypa Brood, 1978}

Type species. - Radiotrypa gothica Brood, 1978. Hirnantian (Upper Ordovician) of Borenshult (Sweden).

Diagnosis. - Following Ernst et al. (2015) Radiotrypa is characterized by having branched colonies, with endozone and exozone well defined. Autozooecia budding in 8-12 radial series from the central part of the branch, with 2-4 autozooecial rows per series. Radial autozooecial groups are separated by a layer produced by the thickening of autozooecial walls in neighbouring series. Autozooecial diaphragms rare to absent. Acanthostyles can be present. Exilazooecia present, rounded to polygonal in shape. Maculae not observed.

\section{Radiotrypa sp.}

Figure 5A, B, Table 7

Material. - MPZ 2015/1546-1548.

Description. - Ramose zoarium with an average branch diameter of $1.7 \mathrm{~mm}$; endozone $1.05 \mathrm{~mm}$ of average diameter and exozone $0.38 \mathrm{~mm}$ of average width. Autozooecial apertures with an apparent diameter of $0.12 \mathrm{~mm}$ on average (measured in longitudinal sections); autozooecial cross section irregularly polygonal in endozone, where they grow as long tubes parallel to branch axis; in internal exozone they gently bend forming an average angle of $49^{\circ}$ with zoarial surface; arranged in 8 radial series separated by laminae that protrude as low ridges on colony surface, with 2-4 autozooecial rows per series; diaphragms scarce, present in external endozone with no more than one or two per autozooecium. Autozooecial walls laminated, with an average thickness of $0.016 \mathrm{~mm}$ in endozone and $0.045 \mathrm{~mm}$ in exozone. Laminae separating autozooecial radial series with laminar microstructure, thicker than autozooecial walls in endozone but thinner in exozone. Exilazooecia and acanthostyles absent.

Remarks. - The arrangement of autozooecia in radial series from the central part of the branch, with these series separated by a laminated layer produced by the thickening of autozooecial walls in neighbouring series, together with the scarcity of autozooecial diaphragms, have been the diagnostic characters that have allowed us to include these specimens in Radiotrypa.

Radiotrypa sp. described here can be easily distinguished from $R$. alnifensis Ernst et al., 2015 (described in Ernst et al. 2015, in the Upper Ordovician glaciogenic deposits of Alnif, Morocco) because the latter has abundant exilazooecia and acanthostyles are present.

Occurrence. - Radiotrypa sp. is exclusive from the Khabt-el-Hajar Formation in the horizon MN4, eastern Moroccan Anti-Atlas (Upper Ordovician, upper Katian).

Family Heterotrypidae Ulrich, 1890

\section{Genus Heterotrypa Nicholson, 1879}

Type species. - Monticulipora frondosa d'Orbigny, 1850. Upper Ordovician (Cincinnatian) of North America.

Diagnosis. - Following Ernst \& Key (2007) the genus Heterotrypa is characterized by its frondose, ramose or encrusting colonies with monticules generally composed of a small central cluster of mesozooecia. Autozooecial diaphragms generally scarce in endozone and more abundant in exozone, where they are thin, planar, perpendicular to zooecial walls and regularly spaced; autozooecial walls with variable thickness. Intermonticular mesozooecia range from abundant to absent; commonly develop moniliform chambers at proximal ends and tend to become smaller or are terminated distally within exozone; mesozooecial 

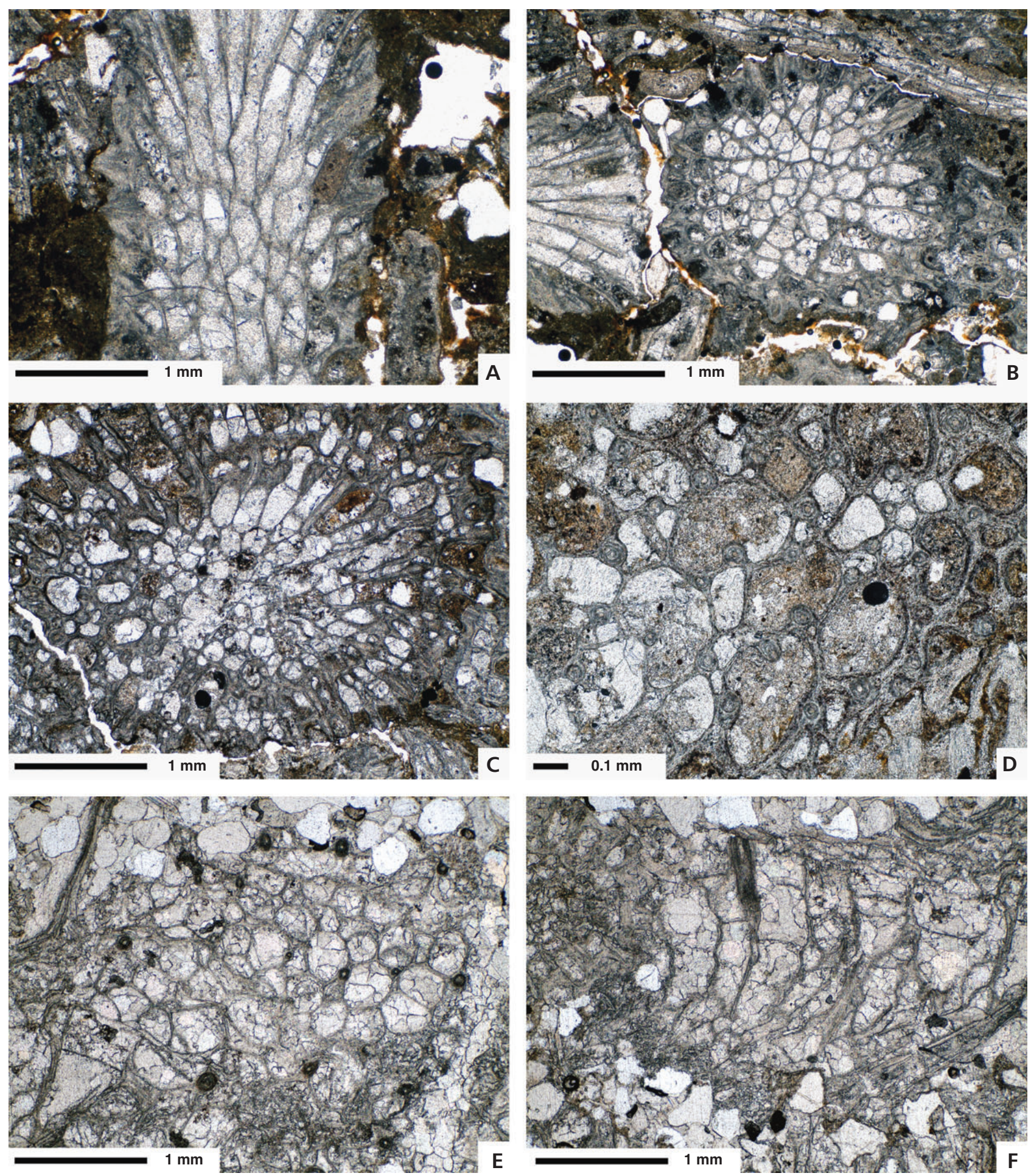

Figure 5. A, B - Radiotrypa sp., A - longitudinal section of specimen MPZ 2015/1547; B - transversal section of specimen MPZ 2015/1548. - C-D - Heterotrypa sp., specimen MPZ 2014/551; C - transversal section, and D - longitudinal section showing large acanthostyles modifying autozooecial cross-sections. E E, F - Dekayia minima Conti, 1990, specimen MPZ 2014/552; E - transversal section, and F-longitudinal section showing a large acanthostyle. Specimens MPZ 2014/551 and MPZ 2015/1547-1548 from horizon MN4; specimen MPZ 2014/552 from horizon MS5.

diaphragms thicker and more abundant than autozooecial diaphragms. Acanthostyles always present and differentiated into two types: regular acanthostyles limited to exozone, and endacanthostyles originated in both endozone and exozone; only the latter are present in all species. 
Table 8. Summary of the statistical analysis of Heterotrypa sp. Abbreviations as in Table 1 .

\begin{tabular}{lcclcc}
\hline Character & Or & X & SD & Nm & Nsp \\
\hline Acanthostyles diameter & $0.05-0.10$ & 0.08 & 0.010 & 9 & 1 \\
Acanthostyles $/ \mathrm{mm}^{2}$ & $21-25$ & 22 & 2 & 3 & 1 \\
Autozooecial diameter & $0.17-0.29$ & 0.22 & 0.04 & 8 & 1 \\
Autozooecial apertures $/ \mathrm{mm}^{2}$ & $9-13$ & 10 & 2 & 3 & 1 \\
Autozooecial wall thickness & $0.007-0.012$ & 0.011 & 0.002 & 5 & 1 \\
in endozone & & & & & \\
Autozooecial wall thickness & $0.025-0.050$ & 0.037 & 0.009 & 5 & 1 \\
in exozone & 2.9 & 2.9 & 0 & 1 & 1 \\
Branch minimum diameter & 1.7 & 1.7 & 0 & 1 & 1 \\
Endozone minimum diameter & $0.67-0.75$ & 0.70 & 0.05 & 2 & 1 \\
Exozone thickness & $0.07-0.12$ & 0.10 & 0.02 & 8 & 1 \\
Mesozooecial diameter & $17-21$ & 19 & 2 & 3 & 1 \\
Mesozooecial apertures $/ \mathrm{mm}^{2}$ & & & & &
\end{tabular}

Occurrence. - This genus ranges from Middle Ordovician to Devonian and has a wide geographical distribution (North America, Europe, Asia and Northern Africa).

\section{Heterotrypa sp.}

Figure 5C, D, Table 8

Material. - MPZ 2014/551.

Description. - Ramose zoarium with individual branches $2.9 \mathrm{~mm}$ in diameter (measured in only one transverse section); endozone $1.7 \mathrm{~mm}$ in diameter and exozone $0.70 \mathrm{~mm}$ of average width. Autozooecial cross-section $0.22 \mathrm{~mm}$ of average diameter in exozone, irregularly rounded and generally indented by large acanthostyles, with an areal density of 10 apertures $/ \mathrm{mm}^{2}$; throughout endozone autozooecia are long tubes growing almost parallel to branch axis, in internal exozone they bend slightly, intersecting zoarial surface at a gentle angle; autozooecial diaphragms scarce in endozone separated by three or more autozooecial diameters, thin and perpendicular to zooecial walls; diaphragms absent in exozone; autozooecial walls with a microgranular structure in endozone, thin $(0.01 \mathrm{~mm}$ of average thickness) and slightly wavy; in exozone they progressively thicken up reaching an average thickness of $0.037 \mathrm{~mm}$, with laminated microstructure. Mesozooecia abundant, developed in internal exozone, irregular in cross-section showing an average small diameter of $0.10 \mathrm{~mm}$ and an average areal density of 19 apertures $/ \mathrm{mm}^{2}$; mesozooecial diaphragms numerous, spaced less than one mesozooecial diameter; thicker than autozooecial diaphragms and perpendicular to mesozooecial walls; mesozooecia are slightly narrower where diaphragms join to walls. Acanthostyles present in endozone and exozone, large $(0.08 \mathrm{~mm}$ of average diameter $)$ and numerous
(22 acanthostyles $/ \mathrm{mm}^{2}$ of average), generally modifying autozooecial cross-section; composed of a large hyaline core surrounded by dark laminated sheaths; there are no differences between acanthostyles and endacanthoslyles.

Remarks. - The ramose colony, the presence of autozooecial diaphragms in endozone and its shape, the mesozooecial diaphragms thicker and more abundant than autozooecial diaphragms, the moniliform chambers of mesozooecia, as well as the presence of endacanthostyles both in endozone and exozone are characters present in the Moroccan zoarium and they have allowed us to include it in Heterotrypa. However, the presence of autozooecial diaphragms is a character present in all species assigned to this genus and this character is absent in the material described here. Nevertheless, we include the Moroccan zoarium in Heterotrypa because it shows the most important diagnostic characters of the genus. This material does not allow the species identification and is not sufficient for establishing of a new species. Therefore, we left it in the open nomenclature.

Heterotrypa sp. can be distinguished from H. magnopora Boulange, 1963 from the Upper Ordovician of Montagne Noire (southern France), according the original diagnosis and subsequent description by Ernst \& Key (2007), because the latter has numerous autozooecial diaphragms, autozooecia are larger (a range of 0.16-0.39 mm vs $0.17-0.29 \mathrm{~mm}$ in Moroccan zoarium) and acanthostyles are smaller (a range of $0.03-0.08 \mathrm{~mm}$ in French Heterotrypa vs $0.05-0.10 \mathrm{~mm}$ in the Moroccan species). Heterotrypa sp., described by Jiménez-Sánchez (2009) from the Upper Ordovician of Iberian Chains (Spain) is similar to the Moroccan material in size of autozooecia, mesozooecia and acanthostyles, but differs in presence of abundant autozooecial diaphragms.

Occurrence. - This species is known exclusively from the Khabt-el-Hajar Formation, horizon MN4, eastern Moroccan Anti-Atlas (Upper Ordovician, upper Katian).

\section{Genus Dekayia Milne-Edwards \& Haime, 1851}

Type species. - Dekayia aspera Milne-Edwards \& Haime, 1851, Upper Ordovician of North America.

Diagnosis. - Following Ernst \& Key (2007) the genus Dekayia is characterized by having ramose, encrusting or massive zoarium, generally with low monticules; autozooecial diaphragms scarce, typically absent in endozone and widely sparse or even absent in exozone; zooecial walls crenulated to undulating and irregularly thick in exozone; mesozooecia rare or absent in intermonticular area; as well as acanthostyles present in endozone and exozone, placed mainly in zooecial corners. 
Occurrence. - Upper Ordovician of North America, Europe, North Africa and China and Lower Carboniferous of Russia.

\section{Dekayia minima Conti, 1990}

Figure 5E, F, Table 9

1990 Dekayia minima Conti; Conti, p. 104, pl. 12, figs 4-6, pl. 13, fig. 8 .

2007 Dekayia minima Conti, 1990. - Ernst \& Key, p. 17, pl. 4, figs 12, 13.

Material. - MPZ 2014/552.

Description. - Massive zoarium with small number of megazooecia forming maculae. Autozooecial cross-section round to irregularly polygonal in exozone, with an average diameter of $0.26 \mathrm{~mm}$ and an average areal density of 9.5 apertures $/ \mathrm{mm}^{2}$; diaphragms present only in some autozooecia, but no more than two per autozooecium, placed mainly in the distal part of tubes. Mesozooecia developed in exozone and irregularly polygonal in cross-section; with an average maximum diameter of $0.11 \mathrm{~mm}$ and an average areal density of 5.5 mesozooecia $/ \mathrm{mm}^{2}$; diaphragms not observed. Acanthostyles large $(0.072 \mathrm{~mm}$ of average diameter), but not abundant $\left(3.5 / \mathrm{mm}^{2}\right.$ of average $)$, developed in both endozone and exozone and placed in autozooecial corners; composed of a central hyaline core and dark sheaths surrounding it. Zooecial walls slightly undulating and with irregular thickness $(0.010 \mathrm{~mm}$ of average thickness in exozone and slightly thinner in endozone).

Remarks. - The scarcity of autozooecial diaphragms and its complete absence in mesozooecia; the presence of large acanthostyles in autozooecial corners, both in endozone and exozone; and the undulated and irregular thickness of autozooecial walls are the characters that have allowed us to assign this specimen to the genus Dekayia.

This Moroccan zoarium has been assigned to Dekayia minima since it fits well with the description of this species made by Ernst \& Key (2007) in the Upper Ordovician of the Montagne de Noire and Carnic Alps. Both materials share the massive habit of growth and have similar disposition of autozooecia, mesozooecia and acanthostyles in the colonies; besides, the range of diameters of these structures is similar (for autozooecia a range $0.19-0.30 \mathrm{~mm}$ in Moroccan zoarium $v s \quad 0.16-0.33 \mathrm{~mm}$ in French material; for mesozooecia a range of $0.08-0.15 \mathrm{~mm}$ in Moroccan zoarium vs $0.05-0.19 \mathrm{~mm}$ in French material; and for acanthostyles a range of $0.050-0.010 \mathrm{~mm}$ in Moroccan zoarium vs $0.050-0.080 \mathrm{~mm}$ in French material), so the Moroccan specimen is assigned to D. minima.

The Moroccan $D$. minima can be distinguished from the
Table 9. Summary of the statistical analysis of Dekayia minima Conti, 1990. Abbreviations as in Table 1.

\begin{tabular}{lcclcc}
\hline Character & Or & X & SD & Nm & Nsp \\
\hline Acanthostyles diameter & $0.050-0.10$ & 0.072 & 0.020 & 6 & 1 \\
Acanthostyles $/ \mathrm{mm}^{2}$ & $3.0-4.0$ & 3.5 & 0.7 & 2 & 1 \\
Autozooecial aperture diameter & $0.19-0.30$ & 0.26 & 0.04 & 7 & 1 \\
Mesozooecial diameter & $0.08-0.15$ & 0.11 & 0.03 & 5 & 1 \\
Autozooecial wall thickness & $0.007-0.012$ & 0.010 & 0.002 & 8 & 1 \\
Autozooecial apertures $/ \mathrm{mm}^{2}$ & $9.0-10.0$ & 9.5 & 0.7 & 2 & 1 \\
Mesozooecial apertures $/ \mathrm{mm}^{2}$ & $5.0-6.0$ & 5.5 & 0.7 & 2 & 1 \\
\hline
\end{tabular}

Moroccan Dekayia sp., described by Jiménez-Sánchez et al. (2015b), also in the Khabt-el-Hajar Formation, because Dekayia sp. has more regular polygonal autozooecia, fewer mesozooecia (a range of $0.5-3.0 / \mathrm{mm}^{2}$ in Dekayia sp. vs $5.0-6.0 / \mathrm{mm}^{2}$ in D. minima), larger autozooecia (a range of $0.29-0.43 \mathrm{~mm}$ in Dekayia sp. vs $0.19-0.30 \mathrm{~mm}$ in D. minima), more acanthostyles (a range of $1.2-10.7 / \mathrm{mm}^{2}$ in Dekayia sp. vs $3.0-4.0 / \mathrm{mm}^{2}$ in D. minima) and they are more irregular in longitudinal view.

Occurrence. - Dekayia minima is exclusive of the Upper Ordovician and has been described in the Upper Caradoc (unit $c$ ) of Sardinia (Italy), in the Ashgill of Montagne de Noire (southern France), in the siltstone/sandstone member of the Uggwa Formation (Caradoc to lower Ashgill of Italian Carnic Alps), and in the Khabt-el-Hajar Formation, horizon MS5 from the upper Katian of the eastern Moroccan Anti-Atlas.

Family Mesotrypidae Astrova, 1965

\section{Genus Homotrypa Ulrich, 1882}

Type species. - Homotrypa curvata Ulrich, 1882. Upper Ordovician of Cincinnati (USA).

Diagnosis. - Following Ernst \& Key (2007) the genus Homotrypa is characterized by having ramose and frondose zoaria, sometimes encrusting and irregularly massive in the first stages. Autozooecial apertures polygonal, rounded to oval; autozooecial walls slightly thickened in exozone, with laminated microstructure; diaphragms more abundant in exozone than in endozone, where they can be absent, and cystiphragms only in exozone. Mesozooecia from scarce to abundant, sometimes clustering to form maculae. Acanthostyles abundant and small.

Occurrence. - This genus has a wide geographic range being present from the Middle Ordovician to the Lower Silurian in North America, North Africa, Europe, Australia and Siberia. 
Table 10. Summary of the statistical analysis of Homotrypa miqueli (Prantl, 1940). Abbreviations as in Table 1.

\begin{tabular}{lccccc}
\hline Character & Or & $X$ & SD & Nm & Nsp \\
\hline $\begin{array}{l}\text { Autozooecial angle with zoarial } \\
\text { surface }\end{array}$ & $35^{\circ}-66^{\circ}$ & $46^{\circ}$ & 14.2 & 6 & 1 \\
Autozooecial diameter & $0.12-0.17$ & 0.15 & 0.02 & 4 & 1 \\
Branch minimum diameter & 3.48 & 3.48 & 0 & 1 & 1 \\
Endozone wall thickness & $0.005-0.012$ & 0.007 & 0.003 & 6 & 1 \\
Exozone wall thickness & $0.050-0.100$ & 0.072 & 0.021 & 4 & 1 \\
\hline
\end{tabular}

\section{Homotrypa miqueli (Prantl, 1940)}

Figure 6A, B, Table 10

1940 Homotrypella miqueli Prantl; Prantl, pp. 93-94, pl. 1, fig. 6, pl. 2, figs 8, 9 .

2007 Homotrypa miqueli (Prantl, 1940). - Ernst \& Key, p. 14, pl. 3, figs 9-13.

Material. - MPZ 2014/553.

Description. - Ramose colony with a branch diameter of $3.5 \mathrm{~mm}$ and autozooecial average diameter of $0.15 \mathrm{~mm}$ in exozone (measured in longitudinal section). In endozone autozooecia have long tubes developed parallel to branch axis and with irregular diameter; in internal exozone they gently bend until reaching zoarial surface with an average angle of $46^{\circ}$. Autozooecial diaphragms scarce in endozone, more numerous in endozone-exozone transit and scarce in external exozone; straight in shape, but curved and even sinusoidal forms are also present. Cystiphragms throughout exozone, covering only one side of autozooecial walls (side facing branch axis), and irregular in size within the same autozooecium. Mesozooecia not observed. Acanthostyles scarce, developed inside autozooecial walls in external exozone. Autozooecial walls thin in endozone ( $0.007 \mathrm{~mm}$ of average thickness) and with granular microstructure; in exozone with laminated microstructure and an average thickness of $0.072 \mathrm{~mm}$.

Remarks. - This specimen fits well in the genus Homotrypa since it shares the ramose zoarium; the autozooecial walls thickened in exozone, with laminated microstructure; the presence of diaphragms, more abundant in exozone than in endozone; the presence of cystiphragms only in exozone; and the presence of small acanthostyles. The only diagnostic character that has not been seen in the Moroccan material is the presence of mesozooecia, but we only have one specimen and it is possible that the absence of mesozooecia in this specimen is a consequence of the random longitudinal section.

The described characters of this Homotrypa fit well with the description of $H$. miqueli made by Ernst \& Key (2007) in the Upper Ordovician of Montagne Noire
Table 11. Summary of the statistical analysis of Aostipora sp. Abbreviations as in Table 1.

\begin{tabular}{lcllcc}
\hline Character & Or & X & SD & Nm & Nsp \\
\hline $\begin{array}{l}\text { Autozooecial angle with zoarial } \\
\text { surface }\end{array}$ & $80^{\circ}-89^{\circ}$ & $86^{\circ}$ & 3 & 6 & 1 \\
Autozooecial maximum diameter & $0.14-0.25$ & 0.18 & 0.03 & 19 & 2 \\
Autozooecial minimum diameter & $0.07-0.15$ & 0.11 & 0.02 & 25 & 3 \\
Autozooecial cingulum thickness & $0.020-0.037$ & 0.027 & 0.004 & 14 & 2 \\
$\begin{array}{l}\text { Autozooecia wall thickness } \\
\text { in endozone }\end{array}$ & $0.006-0.010$ & 0.007 & 0.002 & 12 & 3 \\
Branch minimum diameter & $3.8-4.2$ & 4.0 & 0.3 & 2 & 2 \\
Endozone minimum diameter & $2.85-2.92$ & 2.89 & 0.05 & 2 & 2 \\
Exozone thickness & $0.45-0.57$ & 0.52 & 0.04 & 6 & 2 \\
\hline
\end{tabular}

(France) and it is included in this species. In both materials autozooecia reach zoarial surface with similar angle, diaphragms and cystiphragms have the same distribution and similar shape; endozone and exozone autozooecial walls are similar in thickness (endozone: $0.006-0.010 \mathrm{~mm}$ in French material and 0.005-0.012 mm in Moroccan one; exozone: $0.054-0.100 \mathrm{~mm}$ in French material and $0.050-0.100 \mathrm{~mm}$ in Moroccan one). However the autozooecial diameter is different $(0.11-0.25 \mathrm{~mm}$ in French material vs $0.12-0.17 \mathrm{~mm}$ in Moroccan one), but this difference can be explained by the fact that in Moroccan specimen this character has been measured in longitudinal section.

Homotrypa miqueli can be distinguished from $H$. aff. alta Cumings \& Galloway, 1913 described by JiménezSánchez (in Jiménez-Sánchez et al. 2015a), both in the same formation, because the former have smaller autozooecial aperture $(0.12-0.17 \mathrm{~mm}$ vs $0.17-0.46 \mathrm{~mm}$ in $H$. aff. alta), smaller cystiphragms, fewer acanthostyles and mesozooecia are absent in $H$. miqueli as described here.

Occurrence. - Homotrypa miqueli has been described in the Upper Ordovician (Caradoc to Ashgill) of the Montagne Noire (France); in the Uggwa Formation, siltstone and sandstone member (Upper Caradoc to Lower Ashgill) of the Carnic Alps (Italy); and in the Khabt-el-Hajar Formation in the horizon MN4, northeastern Moroccan Anti-Atlas, (Upper Ordovician, upper Katian).

Family Trematoporidae Miller, 1889

\section{Genus Aostipora Vinassa de Regny, 1921}

Type species-Aostipora cystata (Bassler, 1911), Middle Ordovician of Estonia.

Diagnosis. - Following Jiménez-Sánchez in Jiménez-Sánchez et al. (2015b), Aostipora is characterized by having 
ramose zoarium with long autozooecia growing parallel to the branch axis in endozone and curving in exozone to form an angle of up to $90^{\circ}$ with the zoarial surface. Autozooecial cross-section irregularly polygonal in endozone and rounded-polygonal or oval in exozone. Autozooecial diaphragms scarce or absent in endozone and exozone. Autozooecial walls thin in endozone and progressively thicker in exozone, showing a distinct fine lamination. Mesozooecia present, partitioned by both diaphragms and cysts in the same mesozooecium, and sometimes also filled with vesicular tissue; usually mesozooecia are covered by calcitic deposits in the external exozone. Acanthostyles rare or lacking.

Occurrence. - Middle Ordovician of Estonia (Kuckers Shale, Sandbian), Argentina (San Juan Formation, Sandbian), and Upper Ordovician of North Africa.

\section{Aostipora sp.}

Figure 6C, D, Table 11

Material. - MPZ 2014/554-556.

Description. - Ramose zoaria with individual branches $4.0 \mathrm{~mm}$ of average diameter. Autozooecial aperture oval to subcircular, with average maximum and minimum diameters of $0.18 \mathrm{~mm}$ and $0.11 \mathrm{~mm}$, respectively, and surrounded by a thick cingulum of $0.027 \mathrm{~mm}$ of average thickness; separation between adjacent autozooecia is generally larger than its minimum diameter and this space is occupied by calcitic deposits. Autozooecia irregularly polygonal in endozone; here they grow parallel to branch axis and curve gently in external endozone; at the base of exozone autozooecial curvature becomes stronger, forming an average angle of $86^{\circ}$ with zoarial surface. Autozooecial diaphragms only present in some autozooecia, both in endozone and exozone and with a large separation between consecutive diaphragms. Autozooecial walls slightly undulated, thin in endozone $(0.007 \mathrm{~mm}$ of average thickness) and not distinguishable from the cingulum in exozone. Mesozooecia originate in internal exozone and only visible in longitudinal section; their proximal parts are filled by vesicular structures that are covered by calcitic laminar deposit in external exozone. Exozone poorly developed (0.52 $\mathrm{mm}$ of average thickness); endozone $2.89 \mathrm{~mm}$ of average diameter. Acanthostyles absent.

Remarks. - The ramose zoarial growth habit, with long autozooecia growing parallel to the branch axis in endozone and curving in exozone to form sharply angle with the zoarial surface; the shape of autozooecial cross section both in endozone and exozone, the scarcity of autozooecial diaphragms; and especially the presence of numerous me- sozooecia filled with calcitic deposits, that prevent seeing them in the external colonial surface, and the presence of vesicular structures inside these mesozooecia have allowed us to include this material in the genus Aostipora. But, the described material does not fit well with any known Aostipora species and it is insufficient for establishing of a new species, so we left it in open nomenclature to the species level.

Aostipora sp. differs from A. elongata JiménezSánchez in Jiménez-Sánchez et al. (2015b), described also in the Khabt-el-Hajar Formation, in the absence of elongated-flattened macula composed of a calcitic deposit, in the lack of tubules (not real acanthostyles), and in the smaller exozone/endozone ratio (0.18 in Aostipora sp. vs 0.36 in A. elongata).

Occurrence.-Aostipora sp. is known exclusively from the Khabt-el-Hajar Formation, horizon MN4, eastern Moroccan Anti-Atlas (Upper Ordovician, upper Katian).

\section{Genus Trematopora Hall, 1852}

Type species. - Trematopora tuberculosa Hall, 1852, Lower Silurian of North America.

Diagnosis. - Following Ernst \& Key (2007) Trematopora is characterized by having branched colonies; autozooecial apertures oval to rounded and with peristome, autozooecial diaphragms scarce and often absent in endozone; mesozooecia numerous and densely tabulated by diaphragms, with thin walls and beaded in internal exozone; near surface mesozooecial walls become thicker and in zoarial surface mesozooecial apertures are completely cover by calcitic laminated skeleton; acanthostyles abundant, often arranged near peristome or in mesozooecial walls.

Occurrence. - Upper Ordovician to Upper Silurian of Europe, North America and Asia, as well as Upper Ordovician of North Africa. Some species have been also described in the Middle Devonian of Europe and North America, as well as in the Lower Carboniferous of North America.

\section{Trematopora sardoa (Vinassa de Regny, 1942)} Figure 6E, F, Table 12

1942 Leptotrypella? sardoa Vinassa de Regny; Vinassa de Regny, pp. 1039-1040, pl. 3, figs 9-12.

?1950 Trematopora clariondi (Vinassa de Regny, 1942). Termier \& Termier, p. 16, 19, pl. 64, figs 9-15.

1963 Trematopora hirsuta (Vinassa de Regny, 1942). Boulange, pp. 38-39, pl. 1, fig. 5a, b.

1990 Trematopora sardoa (Vinassa de Regny, 1942). Conti, pp. 95-96, pl. 4, figs 7, 8, pl. 5, figs 1-4. 
Table 12. Summary of the statistical analysis of Trematopora sardoa (Vinassa de Regny, 1942). Abbreviations as in Table 1.

\begin{tabular}{|c|c|c|c|c|c|}
\hline Character & Or & $\mathrm{X}$ & SD & $\mathrm{Nm}$ & Nsp \\
\hline Acanthostyles diameter & $0.037-0.087$ & 0.064 & 0.016 & 10 & 2 \\
\hline Acanthostyles $/ \mathrm{mm}^{2}$ & $16-40$ & 27 & 8 & 7 & 2 \\
\hline $\begin{array}{l}\text { Autozooecial angle with zoarial } \\
\text { surface }\end{array}$ & $44^{\circ}-76^{\circ}$ & $62^{\circ}$ & 12 & 7 & 2 \\
\hline Autozooecial maximum diameter & $0.14-0.20$ & 0.16 & 0.02 & 10 & 2 \\
\hline Autozooecial minimum diameter & $0.07-0.12$ & 0.10 & 0.01 & 10 & 2 \\
\hline $\begin{array}{l}\text { Autozooecial wall thickness } \\
\text { in exozone }\end{array}$ & $0.020-0.030$ & 0.026 & 0.003 & 10 & 2 \\
\hline Autozooecia/mm $\mathrm{mm}^{2}$ & $10.0-16.0$ & 12.7 & 2.7 & 6 & 2 \\
\hline Branch minimum diameter & 3.4 & 3.4 & 0 & 1 & 1 \\
\hline Endozone minimum diameter & 2.0 & 2.0 & 0.0 & 1 & 1 \\
\hline Exozone thickness & $0.68-0.81$ & 0.75 & 0.06 & 3 & 1 \\
\hline
\end{tabular}

2007 Trematopora sardoa (Vinassa de Regny, 1942). Ernst \& Key, pp. 29-30, pl. 9, figs 8-11.

Material. - MPZ 2014/562-566.

Description. - Ramose zoaria with individual branches $3.4 \mathrm{~mm}$ of diameter (measured in only one transversal section); endozone $2.0 \mathrm{~mm}$ of diameter and exozone $0.75 \mathrm{~mm}$ of average width. Autozooecial cross-section oval in exozone, with average maximum and minimum diameters of $0.16 \mathrm{~mm}$ and $0.10 \mathrm{~mm}$, respectively, and an average of 12.7 autozooecia $/ \mathrm{mm}^{2}$; in endozone autozooecia are long tubes growing parallel to branch axis; in internal exozone they strongly bend, forming an average angle of $62^{\circ}$ with zoarial surface. Autozooecial walls thin in internal endozone, slightly undulated and without distinguishable microstructure; in external endozone they progressively thickened until reaching an average thickness of $0.026 \mathrm{~mm}$ in external exozone, showing a clear laminated microstructure. Autozooecial diaphragms scarce, straight in shape, and present only in internal exozone. Mesozooecia abundant, developed in external endozone, but only visible in longitudinal section since they are covered by a thick laminated calcitic deposit; no more than two or three diaphragms per mesozooecia, straight or slightly curve. Acanthostyles large $(0.064 \mathrm{~mm}$ of average diameter) and numerous $\left(27 / \mathrm{mm}^{2}\right)$; composed of a large hyaline lumen surrounded by dark concentric sheaths; they appear in external exozone and are located near autozooecial walls, but without modifying them.

Remarks. - The oval shape of autozooecial apertures; the scarcity of autozooecial diaphragms; the abundance of mesozooecia covered by calcitic deposits in the zoarial surface; as well as the large size and number of acanthostyles have allow us to include this material in the genus Trematopora. Trematopora sardoa is the most common species of Trematopora in the Mediterranean region and these spe- cimens have been included in this species since they show its diagnostic characters (average size of the colonies and its polymorphs, oval autozooecial apertures, scarcity of autozooecial diaphragms and abundance of mesozooecia).

Trematopora filalensis Termier \& Termier, 1950 and T. clariondi Termier \& Termier, 1950 were also described in the horizon Blue Limestones of the Khabt-el-Hajar Formation. The authors provided some statistical data and some schematic pictures of these species, but they did not describe them in detail. Based on these pictures, T. filalensis can be distinguished from T. sardoa as described here because the former has circular to oval autozooecial apertures and autozooecial diaphragms are present in endozone. However, the pictures of $T$. clariondi, as well as the statistical data (except for the branch diameter), show that it is very similar to our material and to the material of other regions assigned to $T$. sardoa. We are quite sure that $T$. clariondi is a junior synonymous of $T$. sardoa, but it has been impossible for us to examine Termier \& Termier's (1950) material, since it is private and its storage location is unknown.

The material assigned here to Trematopora sardoa can be distinguished from T. gracile Ernst \& Key, 2007 and T. acanthostylita Jiménez-Sánchez, 2009 (the other two Trematopora species described in the Mediterranean region) because $T$. gracile has autozooecial diaphragms in the endozone and acanthostyles develop from the internal exozone. From T. acanthostylita can be distinguished because in this species the autozooecial apertures are completely inflected by the acanthostyles.

Occurrence. - This species has been described in the Upper Caradoc-Lower Ashgill of Montagne Noire (southern France), in the Upper Caradoc-Lower Ashgill (units c and e) of Sardinian (Italy), and in the Khabt-el-Hajar Formation in horizons Blue Limestones, MN4 and MS5, northeastern Moroccan Anti-Atlas, (Upper Ordovician, upper Katian).

Trematopora vesiculata sp. nov.

Figure 7A-C, Table 13

Type species. - Holotype: MPZ 2014/568. Paratypes: MPZ 2014/567 and MPZ 2014/569.

Type horizon and locality. - Merzane North section, horizon 4. Upper Katian (Upper Ordovician) of Morocco.

Material. - MPZ 2014/567-569.

Etymology. - After the presence of vesicular tissue in mesozooecia.

Diagnosis. - Trematopora characterized by the presence of thick vesicular tissue in mesozooecia. 

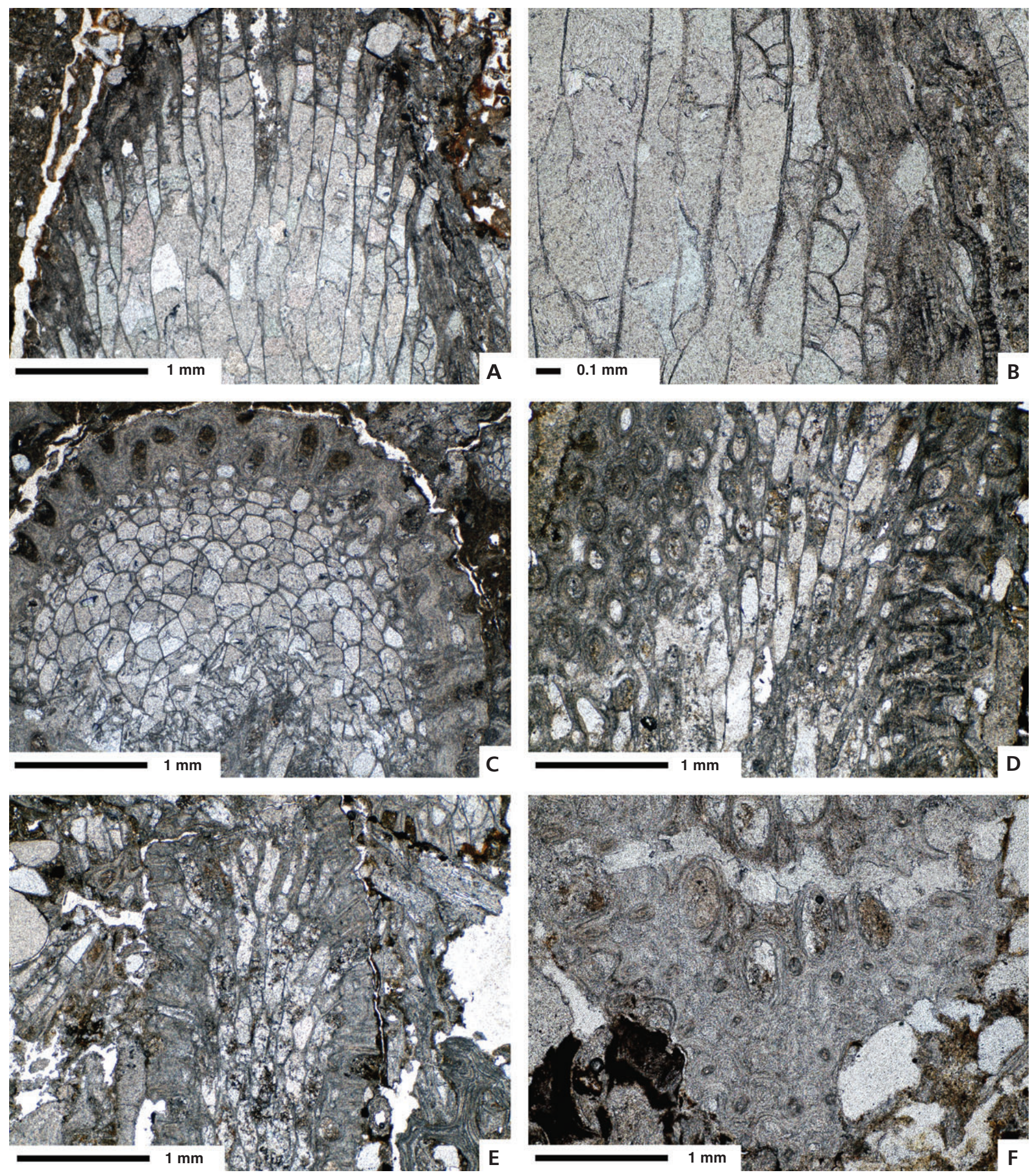

Figure 6. A, B - Homotrypa miqueli (Prantl, 1940), longitudinal sections of specimen MPZ 2014/553. • C, D -Aostipora sp.; C-transversal section of specimen MPZ 2014/555; D - inclined section of specimen MPZ 2014/554. • E, F - Trematopora sardoa (Vinassa de Regny, 1942), specimen MPZ 2014/563; E - longitudinal section, and F - tangential section showing large acanthostyles. All specimens from horizon MN4.

Description. - Ramose zoaria with individual branches $3.8 \mathrm{~mm}$ (measured only in one transversal section); endozone $2.3 \mathrm{~mm}$ in diameter and exozone $0.76 \mathrm{~mm}$ of average width. Autozooecial cross-section rounded to slightly oval in exozone, with an average diameter of $0.12 \mathrm{~mm}$; in endozone autozooecia are long tubes growing parallel to branch 
Table 13. Summary of the statistical analysis of Trematopora vesiculata sp. nov. Abbreviations as in Table 1.

\begin{tabular}{lccccc}
\hline Character & Or & X & SD & Nm & Nsp \\
\hline Acanthostyles diameter & $0.050-0.125$ & 0.076 & 0.021 & 19 & 3 \\
Autozooecial angle with zoarial & $72.0^{\circ}-86.0^{\circ}$ & $79.4^{\circ}$ & 4.3 & 7 & 2 \\
surface & & & & & \\
Autozooecial aperture diameter & $0.10-0.16$ & 0.12 & 0.02 & 18 & 3 \\
Autozooecial wall thickness & $0.020-0.030$ & 0.025 & 0.002 & 8 & 1 \\
Branch thickness & 3.8 & 3.8 & 0 & 1 & 1 \\
Endozone diameter & 2.3 & 2.3 & 0 & 1 & 1 \\
Exozone width & $0.75-0.80$ & 0.76 & 0.02 & 4 & 1 \\
\hline
\end{tabular}

Table 14. Summary of the statistical analysis of Trematopora sp. Abbreviations as in Table 1.

\begin{tabular}{lccccc}
\hline Character & Or & X & SD & Nm & Nsp \\
\hline Acanthostyles diameter & $0.025-0.05$ & 0.037 & 0.009 & 5 & 2 \\
Autozooecial angle with zoarial & $59^{\circ}-90^{\circ}$ & $77^{\circ}$ & 13 & 7 & 2 \\
surface & & & & & \\
Autozooecial minimum diameter & $0.07-0.12$ & 0.10 & 0.02 & 10 & 2 \\
Autozooecial wall thickness & $0.025-0.040$ & 0.033 & 0.006 & 7 & 2 \\
Exozone thickness & $0.37-0.55$ & 0.49 & 0.05 & 7 & 2 \\
\hline
\end{tabular}

axis; in internal exozone they strongly bend, forming an average angle of $79.4^{\circ}$ with zoarial surface. Autozooecial walls thin in internal endozone, without distinguishable microstructure; in external endozone they progressively thicken until reaching an average thickness of $0.025 \mathrm{~mm}$ in external exozone, with a clear laminated microstructure. Autozooecial diaphragms present only in some tubes, but no more than one per autozooecium; when present, they are straight, thick and placed in endozone or exozone. Mesozooecia abundant, developed in internal exozone, but only visible in longitudinal section since they are covered by a thick laminated calcitic deposit; mesozooecial diaphragms scarce, but thick when present; most part of mesozooecial tube filled by vesicular tissue and calcitic deposit. Acanthostyles large, $0.076 \mathrm{~mm}$ of average diameter, and no more than two per autozooecium; composed of a large hyaline lumen surrounded by dark concentric sheaths; they start in internal exozone and are located near autozooecial walls, but without modifying them.

Remarks. - The rounded shape of autozooecial apertures; the scarcity of autozooecial diaphragms, absent in most autozooecia; the abundance of mesozooecia covered by calcitic deposits in the zoarial surface; the large size of acanthostyles; as well as the microstructures of zooecial walls have allow us to assign this material to the genus Trematopora. However, no Trematopora species has been described as having the thick vesicular tissue observed in these Moroccan specimens. So, we define the new species Trematopora vesiculata to include them.
Trematopora vesiculata can be easily distinguished from $T$. sardoa, previously described, because the latter does not have vesicular tissue in mesozooecia, acanthostyles are more abundant and smaller in diameter (a range of $0.037-0.087 \mathrm{~mm}$ in $T$. sardoa vs $0.050-0.125 \mathrm{~mm}$ in $T$. vesiculata) and autozooecia reach the zoarial surface at a less sharp angle (a range of $44^{\circ}-76^{\circ}$ in $T$. sardoa vs $72^{\circ}-86^{\circ}$ in $T$. vesiculata). The new species can be distinguished from T. filalensis Termier \& Termier, 1950 because the latter lacks vesicular tissue in mesozooecia.

Occurrence. - This species is exclusive from the Khabtel-Hajar Formation, horizon MN4, in the northeastern Moroccan Anti-Atlas (Upper Ordovician, upper Katian).

\section{Trematopora sp.}

Figure 7D, E, Table 14

Material. - MPZ 2014/570-571.

Description. - Ramose zoarium, with exozone $0.49 \mathrm{~mm}$ of average width. Autozooecial cross-section subcircular in exozone, with an average diameter of $0.10 \mathrm{~mm}$; in endozone autozooecia are long tubes growing parallel to branch axis, in internal exozone they bend abruptly forming an average angle of $77^{\circ}$ with zoarial surface. Autozooecial walls thin in endozone, slightly undulated and without distinguishable microstructure; in internal exozone they began thickening until reaching $0.033 \mathrm{~mm}$ of average thickness near zoarial surface, with a clear laminated microstructure. Autozooecial diaphragms can be present in endozone and exozone, but no more than one or two per autozooecium, straight in shape. Mesozooecia abundant, one or two rows separating each autozooecium, developed in internal exozone when autozooecia bend; only visible in longitudinal section since they are covered by a thick laminated calcitic deposit; mesozooecial diaphragms scarce and extremely thick. Acanthostyles numerous and with an average diameter of $0.037 \mathrm{~mm}$; composed of a hyaline lumen surrounded by dark concentric sheaths; they appear at different depths in exozone and are located mainly between mesozooecia.

Remarks. - The subcircular shape of autozooecial apertures, the scarcity of autozooecial diaphragms, the abundance of mesozooecia covered by skeletal deposits in the zoarial surface, as well as the large number of acanthostyles have allow us to include this material in the genus Trematopora. However these specimens do not fit well in any of the known Trematopora species. It could be a new species, but we do not have the appropriate sections to define it. So, we leave these specimens in open nomenclature to the species level. 

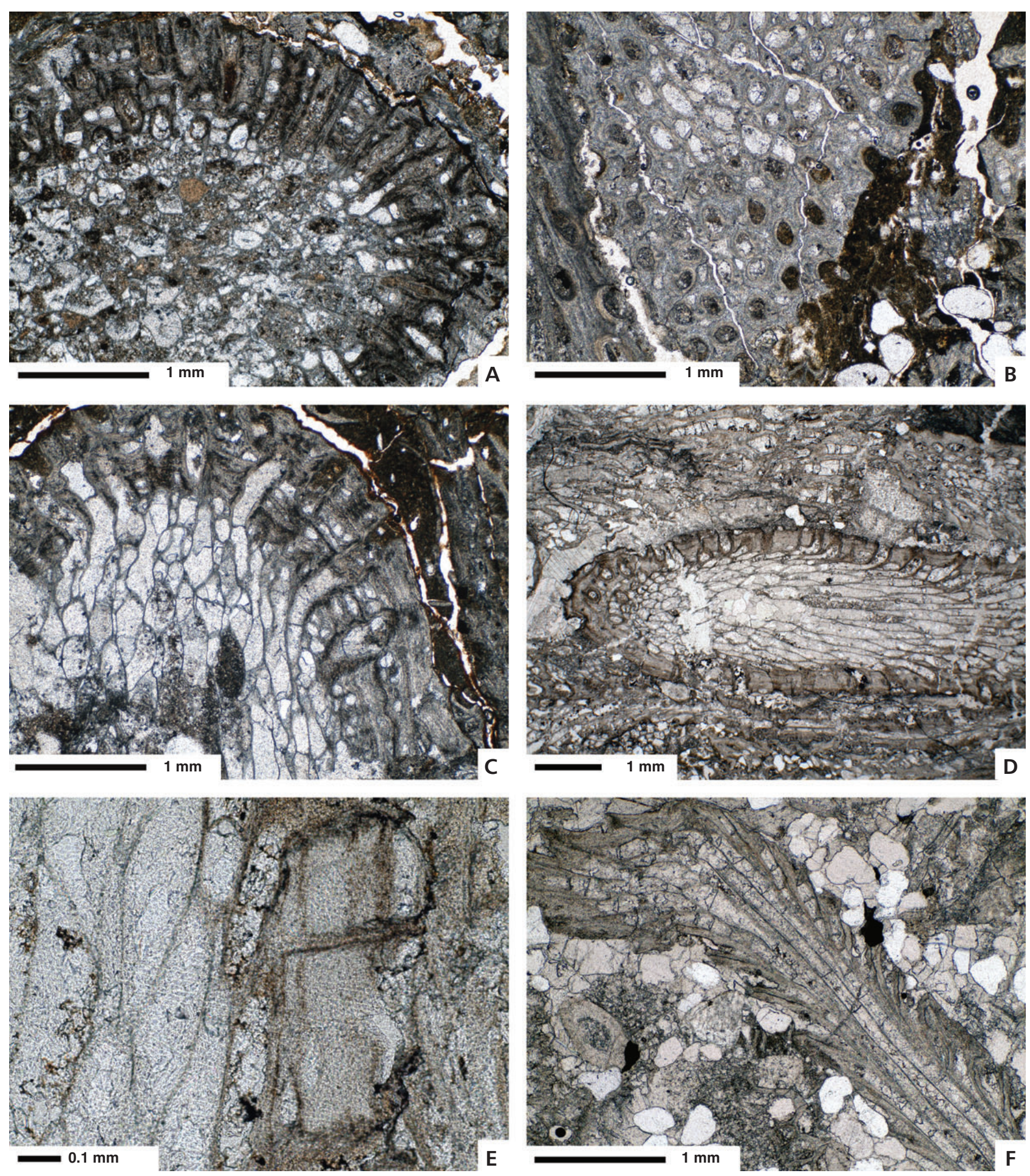

Figure 7. A-C - Trematopora vesiculata sp. nov.; A - transverse section of specimen MPZ 2014/569; B - tangential section of specimen MPZ 2014/567; C - longitudinal section of specimen MPZ 2014/568 (holotype); in Figs A and C is shown vesicular tissue in mesozooecia. - D, E - Trematopora sp.; D - longitudinal section of specimen MPZ 2014/571; E - detailed longitudinal section of specimen MPZ 2014/570 showing large acanthostyles. • F - ? Eridotrypa sp. longitudinal section of specimen MPZ 2014/560. Specimens MPZ 2014/567-569 from horizon MN4; specimens MPZ 2014/570-571 from horizon MS1; specimen MPZ 2014/560 from horizon MS5. 
Table 15. Summary of the statistical analysis of ?Eridotrypa sp. Abbreviations as in Table 1 .

\begin{tabular}{lccccc}
\hline Character & Or & X & SD & Nm & Nsp \\
\hline $\begin{array}{l}\text { Autozooecial angle with zoarial } \\
\text { surface }\end{array}$ & $18^{\circ}-36^{\circ}$ & $26^{\circ}$ & 6 & 10 & 4 \\
$\begin{array}{l}\text { Autozooecial diameter } \\
\begin{array}{l}\text { Autozooecial wall thickness } \\
\text { in endozone }\end{array}\end{array}$ & $0.15-0.25$ & 0.19 & 0.04 & 7 & 3 \\
$\begin{array}{l}\text { Autozooecial wall thickness } \\
\text { in exozone }\end{array}$ & $0.005-0.012$ & 0.011 & 0.002 & 14 & 5 \\
\hline
\end{tabular}

Trematopora sp. can be distinguished from T. sardoa, previously described here, because in the former autozooecial apertures are subcircular, diaphragms can be present in endozone and in exozone and acanthostyles have a smaller diameter. From T. vesiculata can be distinguished, besides the presence of vesicular tissue in the new species, because Trematopora sp. has smaller acanthostyles (a diameter range of $0.025-0.050 \mathrm{~mm}$ in Trematopora sp. vs $0.050-0.125 \mathrm{~mm}$ in $T$. vesiculata). Trematopora $\mathrm{sp}$. is similar to Trematopora sp. 1 described by Ernst \& Key (2007) in the Upper Ordovician of the Montagne Noire (France), but they can be distinguished because in French species diaphragms are more abundant in exozone and acanthostyles develop from the base of the exozone.

Occurrence. - Trematopora sp. is exclusive from the Khabt-el-Hajar Formation in the horizon MS1, eastern Moroccan Anti-Atlas (Upper Ordovician, upper Katian).

Suborder Esthonioporina Astrova, 1978

Family Aisenvergiidae Dunaeva, 1964

\section{Genus Eridotrypa Ulrich, 1893}

Type species. - Cladopora aedilis Eichwald, 1855 (= Eridotrypa mutabilis Ulrich, 1893). Middle Ordovician of Estonia.

Diagnosis. - Following Ernst \& Key (2007) Eridotrypa is characterized by having ramose colonies with narrow exozone; autozooecia weakly bending towards zoarial surface, with oval to oval-rounded apertures and arranged in diagonal rows; autozooecial walls thick and with obliquely laminated microstructure in exozone; autozooecial diaphragms present in endozone and exozone; mesozooecia rare, short, differently closed at colony surface; acanthostyles scarce, small and short when present.

Occurrence. - This genus range from Lower Ordovician to Middle Devonian and has a wide geographical distribution (North America, North Africa, Europe, Siberian, and Asian).
?Eridotrypa sp.

Figure 7F, Table 15

Material. - MPZ 2014/557-562.

Remarks. - The description of this species is based exclusively on the study of longitudinal sections, so autozooecial diameters are apparent and the relationship between endozone and exozone is qualitative and not quantitative.

Description. - Ramose colony with narrow exozone. Autozooecial apertures $0.19 \mathrm{~mm}$ of average diameter; throughout endozone autozooecia are long tubes growing parallel to branch axis, in internal exozone they bend slightly, intersecting zoarial surface with an average angle of $26.5^{\circ}$; diaphragms present throughout autozooecial tube, scarce in endozone, separated by more than two autozooecial diameters, and more numerous in exozone, separated approximately by one and half autozooecial diameters, always thin and perpendicular to walls; autozooecial walls with microgranular microstructure in endozone, thin $(0.011 \mathrm{~mm}$ of average thickness) and straight; from internal exozone they progressively thicken until reaching an average thickness of $0.066 \mathrm{~mm}$ in zoarial surface, here with obliquely laminated microstructure and a dark thick line separating autozooecial walls. Mesozooecia and acanthostyles not observed.

Remarks. - The features described in these Moroccan longitudinal sections fit well with the diagnosis of the genus Eridotrypa since they share the ramose zoaria with poorly developed exozone, the autozooecia intersecting zoarial surface at a low angle, the autozooecial walls thick and with obliquely laminated microstructure in exozone; the presence of autozooecial diaphragms in endozone and exozone, and, in this case, the absence of mesozooecia and acanthostyles, but neither tangential nor transverse sections have been studied and nothing is known about the shape of autozooecial apertures and its arrangement in zoarial surface. So, we cannot be completely sure that this material belongs to Eridotrypa.

Occurrence. - ?Eridotrypa sp. is known exclusively from the Khabt-el-Hajar Formation, horizons MN4 and MS5, eastern Moroccan Anti-Atlas (Upper Ordovician, upper Katian).

Suborder Halloporina Astrova, 1965

Family Halloporidae Bassler, 1911

\section{Genus Parvohallopora Singh, 1979}

Type species. - Monticulipora ramosa d'Orbigny, 1850. Lower Silurian of Cincinnati (Ohio, USA). 

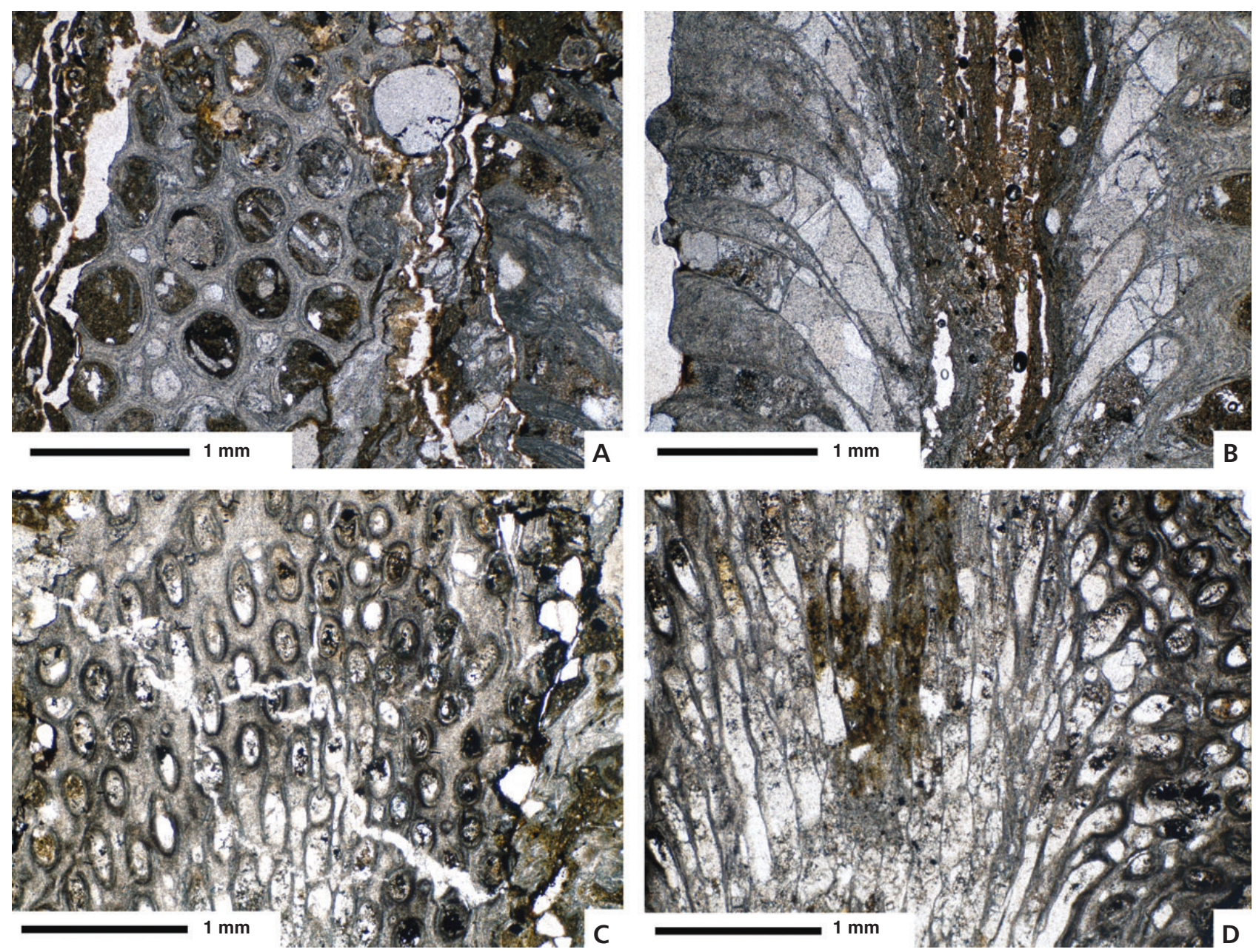

Figure 8. A, B - Parvohallopora sp. 1; A - tangential section of specimen MPZ 2014/548; B - longitudinal section of specimen MPZ $2014 / 547$. - C, D - Trepostomate sp. indet., inclined sections of specimen MPZ 2014/572. All specimens from horizon MN4.

Diagnosis. - Following Singh (1979) Parvohallopora is characterized by having a ramose zoarium with smooth surface or monticules regularly spaced. Exozone well developed with autozooecia forming sharp angles with zoarial external surface. Autozooecial cross-section irregularly polygonal in endozone and polygonal or circular to subcircular in exozone. Autozooecial diaphragms perpendicular to the autozooecial walls or curved, but rarely cystoidal, present throughout autozooecial tube, although they can be absent in exozone in some species. Mesozooecia present and numerous, circular to subcircular in cross-section and with a diameter less than half of those of autozooecia. Mesozooecial diaphragms numerous, perpendicular to mesozooecial walls or curved. Zooecial walls laminated with an inverse $\mathrm{U}$ or $\mathrm{V}$ pattern.

Occurrence. - Middle-Upper Ordovician and Lower Silurian of North America, Upper Ordovician of South America and North Africa (Morocco), Upper Ordovician and Lower Silurian of Europe and Mongolia.

\section{Parvohallopora sp. 1}

Figure 8A, B, Table 16

Material. - MPZ 2014/547-550.

Description. - Zoaria ramose, but with unknown branch diameter because most part of endozone is destroyed and cross-sections are deformed. Autozooecial cross-sections circular to subcircular in exozone, with an average diameter of $0.29 \mathrm{~mm}$ and an average density of 4.2 apertu$\mathrm{res} / \mathrm{mm}^{2}$; autozooecia curving gently in external endozone and sharply bending in internal exozone, forming an average angle of $75^{\circ}$ with zoarial surface; autozooecial diaphragms absent in endozone, scarce in internal exozone and numerous in external exozone, separated by a distance less than 1/2 autozooecial diameter; they are mainly perpendicular to autozooecial walls, but inclined, sinusoidal and even cystoidal shapes are also present; two types of autozooecial diaphragms can be distinguished: the first and most abundant are thin with granular microstructure and 
Table 16. Summary of the statistical analysis of Parvohallopora sp. 1. Abbreviations as in Table 1.

\begin{tabular}{|c|c|c|c|c|c|}
\hline Character & Or & $\mathrm{X}$ & $\mathrm{SD}$ & $\mathrm{Nm}$ & Nsp \\
\hline $\begin{array}{l}\text { Autozooecial angle with zoarial } \\
\text { surface }\end{array}$ & $57.9-88.0$ & 74.8 & 9.8 & 15 & 4 \\
\hline Autozooecial diameter & $0.22-0.37$ & 0.29 & 0.03 & 26 & 5 \\
\hline Autozooecia $/ \mathrm{mm}^{2}$ & $3.0-5.5$ & 4.2 & 1.8 & 2 & 1 \\
\hline Mesozooecial diameter & $0.06-0.17$ & 0.11 & 0.03 & 27 & 5 \\
\hline Mesozooecial diaphragms/mm & $8-18$ & 14 & 2 & 18 & 5 \\
\hline Mesozooecia/mm² & $3.0-6.0$ & 4.5 & 2.1 & 2 & 1 \\
\hline $\begin{array}{l}\text { Zooecial wall thickness } \\
\text { in exozone }\end{array}$ & $0.037-0.150$ & 0.082 & 0.028 & 14 & 3 \\
\hline
\end{tabular}

Table 17. Summary of the statistical analysis of Trepostomate sp. indet. Abbreviations as in Table 1.

\begin{tabular}{lccccc}
\hline Character & Or & X & SD & Nm & Nsp \\
\hline Autozooecial maximum diameter & $0.15-0.25$ & 0.20 & 0.03 & 20 & 2 \\
Autozooecial minimum diameter & $0.09-0.17$ & 0.12 & 0.02 & 20 & 2 \\
$\begin{array}{l}\text { Autozooecial spacing along } \\
\text { branch }\end{array}$ & $0.30-0.55$ & 0.37 & 0.07 & 12 & 2 \\
Autozooecial wall thickness & $0.020-0.037$ & 0.027 & 0.006 & 16 & 2 \\
Mesozooecial diameter & $0.037-0.062$ & 0.052 & 0.009 & 7 & 1 \\
\hline
\end{tabular}

terminate in autozooecial walls; diaphragms of the second type are thick, with laminated microstructure originating from the cortex of autozooecial walls. Mesozooecial cross-sections subcircular to subpolygonal in exozone, with an average diameter of $0.11 \mathrm{~mm}$ and an average density of 4.5 mesozooecia $/ \mathrm{mm}^{2}$; they develop in external endozone and are densely tabulate by diaphragms with an average of 14 diaphragms/mm; diaphragms mainly perpendicular to mesozooecial walls, but thick and laminated cystoidal diaphragms also present, originating from the cortex of wall lamination. Zooecial walls thick in exozone with an average thickness of $0.082 \mathrm{~mm}$ and with a clear laminated microstructure showing an inverse $\mathrm{V}$ pattern.

Remarks. - The sharp angle formed by autozooecia and zoarial external surface, the circular to subcircular shape of autozooecial apertures, the presence of autozooecial diaphragms in exozone, the large number of mesozooecia densely tabulate by diaphragms, as well as the zooecial laminated walls with an inverse $\mathrm{V}$ pattern have allow us to assign these specimens to the genus Parvohallopora. However we have not found a known Parvohallopora species in which this material can be included. It is probably a new species, but we do not have any transversal section and in the longitudinal section most part of the endozone is destroyed, so these characters are unknown. This fact prevents us from defining a new Parvohallopora species and opted instead to leave this material in open nomenclature to the species level.
In the Khabt-el-Hajar Formation (Upper Ordovician of Morocco) P. cystata Jiménez-Sánchez (in JiménezSánchez et al. 2015b) and Parvohallopora sp. (JiménezSánchez et al. 2015b) have been previously described. The new specimens included in Parvohallopora can be distinguished from $P$. cystata because cystoidal diaphragms are abundant in the latter species and it has larger autozooecial diameter $(0.20-0.46 \mathrm{~mm}$ in $P$. cystata vs $0.22-0.37 \mathrm{~mm}$ in Parvohallopora sp. 1 described here). From Parvohallopora sp. described in Jiménez-Sánchez et al. (2015b) this new material can be distinguished because it has less mesozooecia/ $/ \mathrm{mm}^{2}\left(4.5 / \mathrm{mm}^{2}\right.$ in Parvohallopora sp. $1 \mathrm{vs}$ $11.0 / \mathrm{mm}^{2}$ in Parvohallopora sp.), more mesozooecial diaphragms (14/mm in Parvohallopora sp. 1 vs 10/mm in Parvohallopora sp.) and by the absence of megazooecia in Parvohallopora sp. 1.

Occurrence. - Parvohallopora sp. 1 is exclusive from the Khabt-el-Hajar Formation in the horizons MN4 and MS1, eastern Moroccan Anti-Atlas (Upper Ordovician, upper Katian).

Incertae sedis

Trepostomate sp. indet.

Figure 8C, D, Table 17

Material. - MPZ 2014/572-573.

Description. - Ramose zoaria with individual branches 4.0 and $4.7 \mathrm{~mm}$ in diameter. Autozooecial cross-section oval in exozone, with an average minimum and maximum diameters of $0.12 \mathrm{~mm}$ and $0.20 \mathrm{~mm}$, respectively, and arranged in irregular longitudinal rows; longitudinally spaced $0.37 \mathrm{~mm}$ on average; in endozone autozooecia are long tubes growing almost parallel to branch axis, in internal exozone they strongly bend intersecting zoarial surface with a sharp angle, close to $90^{\circ}$. Autozooecial diaphragms absent in both endozone and exozone. Autozooecial walls thin and slightly wavy in endozone, with microgranular microstructure; in internal exozone they progressively thicken until reaching in external exozone an average thickness of $0.027 \mathrm{~mm}$, with a laminated microstructure. Autozooecial apertures separated by a thick calcitic laminated skeleton, showing some small regular rounded vesicles $(0.052 \mathrm{~mm}$ of average diameter) in its base.

Remarks. - The zoaria described here have tangential section very similar to that of the cryptostome genus Oanduellina Pushkin, 1977, since both have oval autozooecial apertures arranged in longitudinal rows, vesicles in the endozone-exozone transition covered by extrazooecial skeleton and exilazooecia are absent. However, in longitudinal 

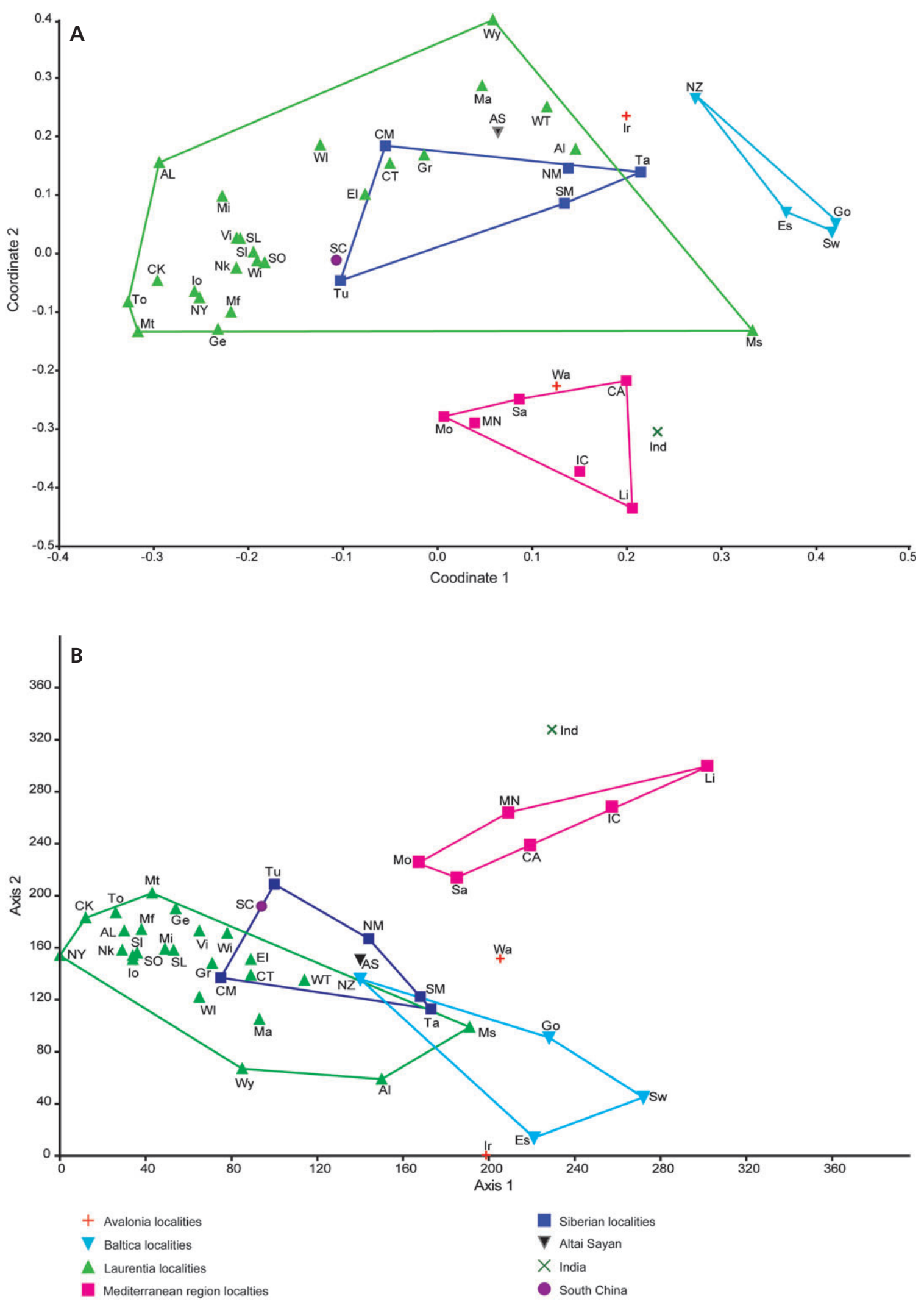

Wa

igure 9. A - principal coordinate analysis ( $\mathrm{PCO})$ using the Dice similarity coefficient; the percentage of total variation contained in each coordinate is: axis $1=14.22 \%$ and axis $2=11.25 \%$. B - detrended correspondence analysis (DCA). See Jiménez-Sánchez \& Villas (2010) fig. 1 and table 1 for abbreviations. 
section these Moroccan zoaria show long autozooecial tubes, difficult to explain in ptilodictyinae genera and easier to fit in trepostomate ones. This is why we have decided to include this material in the Order Trepostomata, in spite of the similarity to the genus Oanduellina in tangential section.

Occurrence. - Trepostomate sp. indet. is known exclusively from the Khabt-el-Hajar Formation, horizon MN4, eastern Moroccan Anti-Atlas (Upper Ordovician, upper Katian).

\section{Palaeogeography affinities of Moroccan bryozoa}

Jiménez-Sánchez \& Villas (2010) carried out a complete Upper Ordovician palaeogeography study based on the distribution of upper Katian bryozoan genera. This work was specially focused on the high and middle-high latitude bryozoans from the Mediterranean region (Carnic Alps, Iberian Chains, Libya, Montagne Noire, Morocco and Sardinia), comparing their palaeogeographic affinities with those of other Gondwana areas (India and Argentinian Precordillera) and also with the other Late Ordovician palaeocontinents (Avalonia, Baltica, Laurentia and Siberia) and South China, located in that period in low and middle-low latitudes. They improved the database of Tuckey (1990) for the upper Katian bryozoans and studied the presence/absence of the 136 known genera in 45 localities from all palaeocontinents (Jiménez-Sánchez \& Villas 2010, fig. 1). This database was analysed for patterns with two multivariate statistical techniques: detrended correspondence analysis (DCA) and principal coordinate analysis (PCO) (Jiménez-Sánchez \& Villas 2010, figs 2-4). For the multivariate analysis to be reliable, only localities with more than 8 identified genera were used. All 45 localities fulfil this constraint except Libya, which only has 7 genera, and Morocco, with 5 genera. They were included in the analysis in order to have a wider view of the palaeogeography of the Mediterranean region. In general terms, the Jiménez-Sánchez \& Villas's (2010) analysis clearly separates these 45 localities according to the palaeocontinent they belong to for the Mediterranean region and Baltica (defining the Baltic and Mediterranean provinces, respectively), but not for Laurentia and Siberia, which plot together forming a single Laurentian-Siberian province, and the two localities of Avalonia, whose position depends on the type of multivariate analysis (DCA or PCO).

In more detail, the localities that form each province (Baltica, Mediterranean region and Laurentia-Siberia) are not at the same distance from the centre of their polygon, and some localities systematically plot far from the centre in one or both of the plots (DCA and PCO). This is the case of Norway in the Baltic province, which plots inside or very close to the point cloud formed by the Mediterranean province localities, and of Missouri in the Laurentian-Siberian province, which plots near the localities of the Baltic province and quite far from the other Laurentian-Siberian localities, both cases in PCO analysis. Also, Morocco and Libya plot quite far from the other Mediterranean localities. Jiménez-Sánchez \& Villas (2010) explained these anomalies as a consequence of the low number of identified genera in the case of Morocco, Libya and Norway (with five, seven and eight known genera, respectively) and by the inclusion of possible Hirnantian fauna coming from the Girardeau Limestone in the case of Missouri.

Ernst \& Nakrem (2011) studied the bryozoans from the Mjosa Formation (Upper Ordovician of Oslo Region), specifically those of the Bergevika member, considered to be of lower Katian age (Bergström et al. 2011). They identified eight genera that were added to the Jiménez-Sánchez \& Villas' (2010) upper Katian database. But, although the results slightly improve those of Jiménez-Sánchez \& Villas (2010), since Norway plots farther away from the Mediterranean group in the PCA and Novaya Zemlya (NZ) place outside of the polygon defined by the Laurentian-Siberian localities in the DCA, we consider not correct to mixing the lower Katian genera from the Mjosa Formation with the upper Katian genera that form the database of JiménezSánchez \& Villas (2010).

Since the palaeogeographic study performed by Jiménez-Sánchez \& Villas (2010), important advances in the knowledge of the upper Katian bryozoans from Moroccan have been made. Jiménez-Sánchez et al. (2015a, b) described 12 genera in the marly facies of the Khabt-el-Hajar Formation, and in the present work other 13 genera are described, ten of them only identified in the calcarenite facies of this formation. These genera have been added to the database of Jiménez-Sánchez \& Villas (2010) making a grand total of 23 genera for Morocco. The updated database has been analysed with the same multivariate techniques employed by Jiménez-Sánchez \& Villas (2010) in order to reassess the palaeogeographic affinity of the Moroccan bryozoans, as only five genera were used in the first analysis. The new results show that Morocco bryozoans, in spite of being the fauna developed in the highest latitudes during the upper Katian, have a clear Mediterranean affinity (Fig. 9). Also, the position of Morocco has improved with respect to the other Mediterranean localities, and now plots closer to the rest, although it is still in one of the vertices of the polygon. This position can be a consequence of the high latitude in which the fauna developed.

The palaeogeographic position of Norway during the upper Katian make difficult to explain it faunistic affinity with the Mediterranean region. On the other hand, the only documented genera of this locality are from the Hirnantian (Brood 1980) and from the lower Katian (Ernst \& Nakrem 
2011), since Tuckey (1990) does not give references of the Norwegian bryozoans included in his database. So, we have removed Norway from the database in this new analysis.

\section{Acknowledgemts}

We would like to acknowledge the financial support to the project EXLIZ CZ.1.07/2.3.00/30.0013, co-financed by the European Social Fund and the state budget of the Czech Republic, as well as to the project CGL2012-39471 of the Spanish Ministry of Economy and Competitiveness. It is also a contribution to the project E-17 "Heritage and Paleontological Museum", from the Department of Science, Technology and University of the Government of Aragón, with participation of the European Social Fund, and the IGCP 591 project " The Early to Middle Paleozoic Revolution". We also thank the technician support to the Servicio General de Apoyo a la Investigación-SAI, Universidad de Zaragoza. Thanks also to Zarela Herrera and Pierre Clement for field assistance.

\section{References}

Álvaro, J.J., Vennin, E., Villas, E., Destombes, J. \& Vizcaïno, D. 2007. Pre-Hirnantian (latest Ordovician) benthic community assemblages: Controls and replacements in a siliciclastic-dominated platform of the eastern Anti-Atlas, Morocco. Palaeogeography, Palaeoclimatology, Palaeoecology 245, 20-36. DOI 10.1016/j.palaeo.2005.09.035

Astrova, G.G. 1965. Morphologiya, istoriya razvitiya i sistema ordoviksikh i siluriyskikh mshanok. Trudy Paleontologischeskogo instituta Akademii nauk SSSR 106, 1-432. [in Russian]

Astrova, G.G. 1978. The history of development, systematics, and phylogeny of the Bryozoa: Order Trepostomata. Trudy Paleontologicheskogo instituta Akademii nauk SSSR 169, 1-240. [in Rusian]

Astrova, G.G. \& Morozova, I.P. 1956. About systematics of the order Cryptostomata. Doklady Akademii nauk SSSR 110(4), 661-664. [in Russian]

BAssLer, R.S. 1911. The early Paleozoic Bryozoa of the Baltic provinces. Bulletin of the United States National Museum, Washington 77, 1-382.

BASSLER, R.S. 1952. Taxonomic notes on genera of fossil and Recent Bryozoan. Journal of the Washington Academy of Sciences 42, 381-385.

Bergström, S.M., Schmitz, B., Young, S.A. \& Bruton, D.L. 2011. Lower Katian (Upper Ordovician) $\delta^{13} \mathrm{C}$ chemostratigraphy, global correlation and sea-level changes in Baltoscandia. GFF 133, 31-47.

DOI 10.1080/11035897.2011.557162

BlaKe, D.B. 1983. Systematic descriptions for the Suborder Rhabdomesina, 551-592. In RoBison, R.A. (ed.) Treatise on Invertebrate Paleontology, Part G. Geological Society of America \& University of Kansas Press, Boulder.

BorG, F. 1926. Studies on Recent cyclostomatous Bryozoa. Zoologiska Bidrag från Uppsala 10, 181-507.

Boulange, M.F. 1963. Sur quelques espèces nouvelles de bryozoaires de l'Ordovicien Supérieur de la Montagne Noire. Bulletin de la Société Géologique de France 7, Série 5, 34-40.
Brood, K. 1978. Upper Ordovician Bryozoa from Dalmantina beds of Boreahult, Östergötland, Sweden. Geologica et Palaeontologica 12, 53-72.

Brood, K. 1980. Late Ordovician Bryozoa from Ringerike, Norway. Norsk Geologistk Tidsskrift 60, 161-173.

Buttler, C.J., Cherns, L. \& Massa, D. 2007. Bryozoan mudmounds from the Upper Ordovician Jifarah (Djeffara) Formation of Tripolitania, North-West Libya. Palaeontology 50, 479-494. DOI 10.1111/j.1475-4983.2007.00636.x

Buttler, C.J. \& Massa, D. 1996. Late Ordovician bryozoans carbonate buildups, Tripolitania, Libya, 63-68. In GoRdon, D.P., SMith, A.M. \& GRAnT-Mackie, J.A. (eds) Bryozoans in Space and Time (Proceeding of the $10^{\text {th }}$ International Bryozoology Conference, Victoria University of Wellington, New Zealand). Niwa, Wellington.

ContI, S. 1990. Upper Ordovician Bryozoa from Sardinia. Palaeontographia Italica 77, 85-165.

Conti, S. \& SERPagli, E. 1988. Bimineralic (calcareous and phosphatic) skeleton in Late Ordovician Bryozoa from Sardinia: geological implications. Bollettino della Società Paleontologica Italiana 27, 129-162.

Cumings, E.R. \& Galloway, J.J. 1913. The stratigraphy and paleontology of the Tanner's reek section of the Cincinnati Series of Indiana. Indiana Department of Natural Resources, $37^{\text {th }}$ Report, 353-478.

Destombes, J., Hollard, D.H. \& Willefert, S. 1985. Lower Palaeozoic rocks of Morocco, 91-336. In Holland, C.H. (ed.) Lower Palaeozoic of north-western and west central Africa. Lower Palaeozoic rocks of the World. John Wiley and Sons, New York.

Dunaeva, N.N. 1964. New bryozoans of the order Trepostomata from Lower Carboniferous of Donbass. Paleontologicheskii zhurnal 2, 39-44. [in Russian]

EichWALD, E. 1855. Beitrag zur geographischen Verbreitung der fossilen Tiere Russlands Alte period. Bulletin de la Société des naturalistes de Moscou 28, 433-466.

El MaAzouz, B. \& Hamoumi, N. 2007. Différenciation paléogéographique à l'Ordovicien supérieur dans le Tafilat (Anto-Atlas oriental, Maroc) sous l'intéraction de la glaciation et de la tectonique. Comptes Rendus Geoscience 339(8), 562-571. DOI 10.1016/j.crte.2007.07.002

Ernst, A. \& CARrera, M. 2012. Upper Ordovician (Sandbian) bryozoan fauna from Argentine Precordillera. Journal of $\mathrm{Pa}$ leontology 86(5), 721-751. DOI 10.1666/12-024.1

ERnst, A., JimÉnEZ-SÁNChez, A. \& BAidder, L. 2015. Bryozoan fauna of the Upper Ordovician (Katian) of Alnif, Morocco. Palaeobiodiversity and Palaeoenvironments. DOI 10.1007/s12549-0208-x

Ernst, A. \& Key, M. 2007. Upper Ordovician bryozoan from the Montagne de Noire, Southern France. Journal of Systematic Palaeontology 5, 359-428. DOI 10.1017/S1477201907002155

ERnSt, A. \& NAKREM, H.A. 2011. Stenolaemate bryozoans from the Mjøsa Formation (Late Ordovician, Katian) of Helgøya (Mjøsa), southern Norway. Norwegian Journal of Geology 91, $163-180$.

GoldFuss, G.A. 1829. Petrefacta Germaniae, Abbildung und Beschreibung der Petrefacten Deutschlands und angrenzender Länder, Band 1, Lieferung 2, 77-164. Arnz and Co., Düsseldorf.

Gorjunova, R.V. \& LavrentJeva, V.D. 1993. Morphology and systematics of the cryptostome bryozoans. Trudy Paleontologicheskogo instituta Rossiiskoi akademii nauk 257, 1-152. [in Russian] 
Hall, J. 1847. Organic remains of the lower division of the New York System. Natural History of New York 6, Palaeontology of New York 1. 338 pp. C. Van Benthuysen, Albany.

HALL, J. 1852. Organic remains of the lower middle division of the New York system. Natural History of New York 6, Palaeontology of New York 2, 40-52, 144-173. C. Van Benthuysen, Albany.

HavlíčEK, V. 1971. Brachiopodes de l'Ordovicien du Maroc. Notes et Mémoires du Service géologique 230, 1-135.

JiMÉNEZ-SÁNCHEZ, A. 2009. The upper Katian (Ordovician) bryozoans from the Eastern Iberian Chains (NE Spain). Bulletin of Geosciences 84, 687-738. DOI 10.3140/bull.geosci.1156

JiMÉNEZ-SÁNCHEZ, A. 2010. New monticuliporidae (Trepostomata) from the Cystoid Limestone Formation (Upper Ordovician) of the Iberian Chains (NE Spain). Geodivérsitas 32, 177-199. DOI 10.5252/g2010n2a1

JiMÉNEZ-SÁNCHEZ, A., ANSTEY, R.L. \& AZANZA, B. 2010. Description and phylogenetic analysis of Iberostomata fombuenensis new genus and species (Bryozoa Ptilodictyina). Journal of Paleontology 84, 695-709. DOI 10.1666/09-068.1

JimÉneZ-SÁnchez, A., SpJeldnaes, N. \& Villas, E. 2007. Ashgill bryozoans from the Iberian Chains (NE Spain) and their contribution to the Late Ordovician biodiversity peak in North Gondwana. Ameghiniana 44, 681-696.

Jiménez-SÁnchez, A., Vennin, E. \& Villas, E. 2015a. Trepostomate bryozoans from the upper Katian (Upper Ordovician) of Morocco: gigantism in high latitude Gondwana platforms. Journal of Paleontology 89, 195-221. DOI 10.1017/jpa.2014.17

JimÉnEZ-SÁncheZ, A. \& Villas, E. 2010. The bryozoan dispersion into the Mediterranean margin of Gondwana during the pre-glacial Late Ordovician. Palaeogeography, Palaeoclimatology, Palaeoecology 294, 220-231. DOI 10.1016/j.palaeo.2009.11.027

JimÉnEZ-SÁncheZ, A., Villas, E. \& Vennin, E. 2015b. New trepostomate bryozoans from the Upper Ordovician of Morocco and the temperature influence on zooid size. Journal of Paleontology 89, 385-404. DOI 10.1017/jpa.2015.20

LavrentueVA, V.D. 1979. A new suborder of Palaeozoic Bryozoa. Paleontologicheskii zhurnal 1, 59-68. [in Russian]

LavrentJeva, V.D. 1985. Bryozoans of the sub-order Phylloporinida. Trudy Paleontologicheskogo instituta Akademii nauk SSSR 214, 1-100. [in Russian]

LoBdell, F. 1992. Arthrostylidae (Bryozoa: Cryptostomata) from the Gunn Member, Stony Mountain Formation (Upper Ordovician), North Dakota and Manitoba. North Dakota Geological Survey Miscellaneous Series 76, 99-115.

Lonsdale, W. 1839. Corals, 675-694. In Murchison, R.I. (ed.) The Silurian System. Part 2. Organic remains. John Murray, London.

Ma, J.Y., ButTler, C.J. \& TAYLOR, P.D. 2014. Cladistic analysis of the gtrepostome h Suborder Esthonioporina and the systematics of Palaeozoic bryozoans, 153-161. In Rosso, A., Wyse Jackson, P.N. \& Porter, J.S. (eds) Bryozoan Studies 2013. Studi Trentini di Scienze Naturali 94.

Meddour, A., Razin, P., Jati, M. \& Rubino, J.L. 2010. Les calcaires à bryozoaires de l'Ordovicien supérieur de l'Anti-Atlas oriental (Maroc): Environment de depot et analyse stratigraphique. Strati 2010. $4^{\text {th }}$ French Congress on Stratigraphy, p. 166.

Miller, S.A. 1889. North American Geology and Paleontology. 664 pp. Western Methodist Book Concern, Cincinnati.
Milne-Edwards, H. \& Haime, J. 1851. Monographie des polypiers fossiles des terrains Paleozoiques. Archives $d u$ Muséum d'Histoire Naturelle 5, 1-504.

Nicholson, H.A. 1879. On the structure and affinities of the "tabulate corals" of the Paleozoic Period, with critical descriptions of illustrative specie. $342 \mathrm{pp}$. William Blackwood and sons, Edinburgh.

Orbigny, A. D' 1850. Note sur quelques espèces nouvelles de Bryozoaires fossiles des terrains crétacés de la France. Espèces de I'étage cénomanien ou de la craie chloritée. Revue et Magazine de Zoologie pure et appliquée 2, 170-181.

Pickerill, R.K. \& Brenchley, P.J. 1979. Caradoc marine communities of the South Berwyn Hills, North Wales. Palaeontology 22, 229-264.

Prantl, F. 1940. Note préliminaire sur les Bryozoaires ordoviciens de la Montagne Noire. Věstník Královské České společnosti nauk 9, 2.

Pushkin, V.I. 1977. New genus of the Ordovician Bryozoan. Paleontologicheskii zhurnal 4, 67-72. [in Russian]

SingH, R.J. 1979. Trepostomatous bryozoan fauna from the Bellevue Limestone, Upper Ordovician in the tri-state area of Ohio, Indiana and Kentucky. Bulletin of American Paleontology 76(307), 161-288.

Termier, G. \& Termier, H. 1950. Paléontologie marocaine. II: Invertebrés de l'ère primaire, pt. 2, Bryozoaires et Brachiopodes, 1-20. Hermann \& Cie, Paris.

TuCKey, M.E. 1990. Biogeography of Ordovician bryozoans. Palaeogeography, Palaeoclimatology, Palaeoecology 77, 91-126. DOI 10.1016/0031-0182(90)90128-T

ULRICH, E.O. 1878. Descriptions of some new species of fossils from the Cincinnati Group. Journal of the Cincinnati Society of Natural History 1, 92-100.

Ulrich, E.O. 1882. American Palaeozoic Bryozoa. The Journal of the Cincinnati Society of Natural History 5, 121-175, 232-257.

UlRICH, E.O. 1886. Report on the Lower Silurian Bryozoa with preliminary descriptions of some of the new species. Minnesota Geology and Natural History Survey $14^{\text {th }}$ Annual Report, 1885, 57-103.

Ulrich, E.O. 1890. Palaeontology of Illinois. Section VI. Palaeozoic Bryozoa. Part II. Report of the Geological Survey of Illinois 8, 283-688.

Ulrich, E.O. 1893. On Lower Silurian Bryozoa of Minnesota. Minnesota Geology and Natural History Survey, Final Report 3, 96-332.

Vennin, E., Alvaro, J.J. \& Villas, E. 1998. High-latitude pelmatozoan-bryozoan mud-mounds from the Late Ordovician northern Gondwana platform. Geological Journal 33, 121-140. DOI 10.1002/(SICI)1099-1034(1998040)33:2< 121::AID-GJ780>3.0.CO;2-D

VinASSA DE REGNY, P. 1921. Sulla classificazione dei trepostomidi. Societa Italiana di Scienze Naturali 59, 212-231.

Vinassa de Regny, P. 1942. Fossili Ordoviciani sardi, Parte II. Atti Reale Accademia Italiana, Memorie di Scienze Fisiche, Matematiche e Naturale 12, 1025-1055.

VINE, G.R. 1884. Fourth report of the Committee consisting of Dr. H.R. Sorby and Mr. G.R. Vine, appointed for the purpose of reporting on fossil Polyzoa. Reports of the $53^{\text {rd }}$ Meeting of British Association for the Advancement in Sciences London, 161-209.

ZitTel, K.A. 1880. Handbuch der Palaeontologie. Abteilung 5. Palaeozoologie. 765 pp. Oldenburg, München. 